\title{
ECONOMIC, DEMOGRAPHIC AND POLITICAL DETERMINANTS OF POLLUTION REASSESSED: A SENSITIVITY ANALYSIS
}

\author{
MARTIN GASSEBNER \\ MICHAEL LAMLA \\ JAN-EGBERT STURM
}

CESIFO WORKING PAPER NO. 1699

CATEGORY 8: RESOURCES AND ENVIRONMENT

APRIL 2006

An electronic version of the paper may be downloaded

- from the SSRN website:

- from the RePEc website:

www.SSRN.com

- from the CESifo website:

www.RePEc.org

www.CESifo-group.de 


\title{
ECONOMIC, DEMOGRAPHIC AND POLITICAL DETERMINANTS OF POLLUTION REASSESSED: A SENSITIVITY ANALYSIS
}

\begin{abstract}
Recent literature proposes many variables as significant determinants of pollution. This paper gives an overview of this literature and asks which of these factors have an empirically robust impact on water and air pollution, i.e. do not depend upon the conditioning information set. For this, we apply Extreme Bound Analysis (EBA) on a panel of 208 countries covering the period 1960-2001. We find supportive evidence on the existence of the environmental Kuznets curve. Furthermore, mainly demographic variables and variables capturing the economic structure of a country contribute in explaining air and water pollution.
\end{abstract}

JEL Code: C52, F18, L60, O13, Q53.

Keywords: pollution, environment, sensitivity analysis, environmental Kuznets curve.

Martin Gassebner

Department of Management, Technology

and Economics

ETH Zurich

Switzerland

gassebner@mtec.ethz.ch
Michael Lamla

Department of Management, Technology

and Economics

ETH Zurich

Switzerland

lamla@mtec.ethz.ch

\author{
Jan-Egbert Sturm \\ Department of Management, Technology and Economics \\ Weinbergstr. 35 \\ ETH - Center, WEH F 11 \\ 8092 Zurich \\ Switzerland \\ sturm@kof.ethz.ch
}

February 2006

We thank Niclas Berggren, Jörg Breitung and Rodger Congleton for their helpful comments. Furthermore, we thank participants of the following conferences and workshops for providing valuable suggestions: XII Conference on Public Economics (3 - 4 February 2005), Palma de Mallorca, Spain; 1st Macroeconomic Research Meeting (4 - 6 March 2005), Kreuzlingen, Switzerland; Annual Meeting of the Swiss Society for Economics and Statistics (17 - 18 March 2005), Zurich, Switzerland; Annual Meeting of the European Public Choice Society (31 March - 3 April 2005), Durham, England; Augustin Cournot Doctoral Days 2005 (6 - 8 April 2005), Strasbourg, France; Silvaplana Workshop on Political Economy (14 - 17 July 2005), Silvaplana, Switzerland. The usual disclaimer applies. 


\section{Introduction}

Facing a rapidly growing population and rising economic activity over the last decades, pollution became a policy issue of increasing importance around the world. Hence, many authors joined the search for determinants of environmental degradation. In earlier studies, researchers to a large extent named production and production-specific variables to be accountable for pollution. Among this type of variables, GDP per capita is in the center of focus. Most authors nowadays believe that its relationship to pollution is non-linear, in the sense that after a certain threshold a higher degree of industrialization even has a positive effect on the environment. Grossman and Krueger (1995) and Selden and Song (1994) were amongst the first to examine this particular relationship, which the latter labeled the environmental Kuznets curve (EKC).

Another line of literature discusses the impact of globalization on pollution. On the one hand, intensive trade patterns accelerate efficient allocations which in turn might lead to lower levels of pollution (see, e.g. Cole (2004)). On the other hand, the so-called pollution haven hypothesis states that globalization causes dirty industrial sectors to be located in countries with low environmental standards (see, e.g. Birdsall and Wheeler (1993)).

Lately, political indicators are introduced into the discussion; the constitutional set-up of a country may explain different levels of pollution. Especially economic and political freedom are used to indicate the conceptual differences between countries and the possible resulting effects on the environment (see, e.g. Neumayer (2003), Carlsson and Lundström (2003) and Bernauer and Koubi (2004)).

Authors like Torras and Boyce (1998) as well as Cole and Neumayer (2004) indicate that demographic factors induce different patterns in pollution levels. For instance, in areas of high density lifestyles are bound to differ from those in more rural regions; these differences in lifestyle might imply differences in environmental pollution.

The empirical literature on the determinants of pollution suffers from some drawbacks. First, as suggested above, a wide variety of variables has been suggested as determinants of environmental contamination and there is little consensus in the literature which variables really matter. Second, most authors do not carefully examine the sensitivity of their findings. Thus, it is hard to tell whether the variables reported to be significant in a particular regression remain robustly related to pollution once other potentially important explanatory variables are included. ${ }^{1}$ Third, the majority of papers only study a rather selective number of variables concentrating on mostly one particular hypothesis; no systematic analysis of the different hypotheses mentioned in the literature are offered. Hence, possible interdependencies with other variables and potential omitted variable biases are generally neglected. A final drawback of some studies is the limited data sample. Often estimations

\footnotetext{
${ }^{1}$ In this paper, the term robustness is used in the sense that the result with respect to one variable is not strongly affected by the set of conditioning variables.
} 
are done for only one country over several years, or for only one year over a cross section of countries.

The aim of this paper is to analyze to what extent various demographic, economic and political variables that have been suggested in the literature as affecting the level of pollution in a country are robust determinants of water and air pollution. For this purpose, we first provide a detailed overview of the literature from which we derive a list of 23 variables. We then estimate a panel model of up to 208 countries over the period 1960-2001 and use so-called Extreme Bounds Analysis (EBA) to examine to what extent these variables are robust determinants of environmental degradation. To the best of our knowledge, this approach to check for the robustness of a relationship has not been used in this line of literature before, although it has been widely employed in for instance the economic growth literature (Levine and Renelt (1992), Sala-i-Martin (1997) and Sturm and de Haan (2005)). As pointed out by Temple (2000), presenting only the results of the model preferred by the author(s) of a particular paper can be misleading. Extreme Bounds Analysis is a fairly neutral means to check robustness issues and compare the validity of conflicting findings in empirical research.

This paper uses biochemical oxygen demand $(B O D)$ as well as carbon dioxide $\left(\mathrm{CO}_{2}\right)$ exhaustion and - to a lesser extent - sulfur dioxide $\left(\mathrm{SO}_{2}\right)$ as measures of pollution. All three are widely accepted environmental proxies which have been well-documented over longer periods of time for most countries in the world.

The remainder of this paper is structured as follows. Section 2 reviews the relevant literature and introduces the variables on which we focus. Section 3 discusses the methodological approach. The results are reported and interpreted in section 4 . The final section summarizes and concludes.

\section{Literature Overview and Variables Selection}

Table A-2 summarizes the studies dealing with the determinants of pollution that have been published since the beginning of the 1990s. As that table makes clear, previous studies have used a wide array of both dependent and explanatory variables. In the 14 studies listed, well over 20 different measures of pollution have been used. The four most often used measures are $\mathrm{CO}_{2}$ and $\mathrm{SO}_{2}$ emissions (to proxy air pollution) plus $B O D$ and the level of dissolved oxygen (to proxy water pollution).

As our measure of water pollution we take $B O D$ from the World Development Indicators CD-ROM (2003) as published by the World Bank (WDI (2003)). According to the European Environment Agency " $B O D$ is a measure of how much dissolved oxygen is being consumed as microbes break down organic matter. A high demand, therefore, can indicate that levels of dissolved oxygen are falling, with potentially dangerous implications for the river's biodiversity." ${ }^{2}$ It is available for a maximum of 114 countries starting in 1980 , i.e. totaling roughly 2,000 observations. The data on water pollution is probably the most accurately measured pollution data, since

\footnotetext{
${ }^{2}$ See http://themes.eea.eu.int/Specific_media/water/indicators/bod/index_html.
} 
sampling techniques are well understood and common in all countries. Additionally, data on water pollution are more readily available than other emissions data as most industrial pollution control programs start by regulating emissions of organic water pollutants. ${ }^{3}$ Since the level of dissolved oxygen is basically the reciprocal to $B O D$ but not as readily available for as many countries, we choose to exclude this measure.

With respect to air pollution, our main variable of interest is the level of $\mathrm{CO}_{2}$ emissions also reported in WDI (2003). ${ }^{4}$ It is available for up to 188 countries covering 1960-1999 with a total of over 6,500 observations. Unfortunately, one has to note that the data are based upon calculations and not measured directly. The original data stem from the Carbon Dioxide Information Analysis Center (CDIAC). Accordingly, "[t]hese calculations are derived from data on fossil fuel consumption, based on the World Energy Data Set maintained by the UNSD and from data on world cement manufacturing based on the Cement Manufacturing Data Set maintained by the U.S. Bureau of Mines." (World Bank (2003b), p. 245-246). Keeping this caveat in mind, these calculations should nevertheless be able to reflect the real pollution level in a sufficient way.

Finally, we have also included $\mathrm{SO}_{2}$ emissions as a pollutant in our setup. The latest and largest data source on $\mathrm{SO}_{2}$ is Stern (2005). To allow comparison with the other two dependent variables, we restrict the data to the time period from 1960 to $2001 .^{5}$ It is available for about 200 countries with a total of over 6,500 observations in our sample. To construct the data set Stern combines various sources and uses different methods: "For the remaining countries and for missing years for countries with some published data, [he] interpolate[s] or extrapolate[s] estimates using either an econometric emissions frontier model, an environmental Kuznets curve model, or a simple extrapolation, depending on the availability of data." (Stern (2005), p. 163). This data gives a decent overview of the evolution of sulfur emission in the past decade for a substantial part of the world. However, it is the most problematic data when applying to our estimation setup. For instance, the above citation makes clear that the environmental Kuznets curve has been used in the data generating process. It will therefore be no surprise to find evidence in favor of an environmental Kuznets curve in our regressions. Hence, the results of this part of our analysis have to be treated with extreme caution, and are therefore not discussed in detail. The results are presented in Table A-6. From this data quality perspective, we will henceforth focus on the results using the $\mathrm{BOD}$ and $\mathrm{CO}_{2}$ variables.

To capture size effects we scale all pollution measures by population. We subsequently take natural logarithms. Our measures of water and air pollution, i.e $B O D$ and $\mathrm{CO}_{2}$, are with a correlation coefficient of 0.762 strongly related to each other (see Table A-3).

The next step is to select our list of explanatory variables. For that we conduct an

\footnotetext{
${ }^{3}$ See also the section "Water Pollution" in World Development Indicators 2005.

${ }^{4}$ Unless mentioned otherwise, all data stem from the WDI (2003) database to ensure consistency.

${ }^{5}$ The original source dates back until 1850.
} 
extensive literature survey. Based upon these previous studies, Table A-2 points out that a rather large and heterogeneous set of variables has been suggested in the past. Furthermore, the empirical results for particular variables are sometimes rather mixed. The remainder of this section will describe the 23 variables, and their underlying hypotheses, which we will use for the further empirical analysis.

From a theoretical point of view, the Environmental Kuznets Curve (EKC) is the most accredited hypothesis. Instead of an inverted U-shaped relationship between income inequality and per capita income - as suggested by Kuznets (1955) - the EKC presumes such a relationship between per capita emissions and per capita income.

A vast number of theories have already been proposed that lead to such an inverted U-shaped relationship, each of them relying on a very specific set of assumptions. Since it is beyond the scope of this paper to discuss the various setups, we only focus on the lines of thought of Grossman and Krueger (1995), Antle and Heidebrink (1995) and Torras and Boyce (1998). ${ }^{6}$ Grossman and Krueger discriminate between a scale, a composition and a technology effect of growth on the environment. The scale effect describes the economic degradation simple due to a boost in economic activity. If economic activity is increasing, more resources are used for production and hence more dissipation occurs. The composition effect describes the change in the structure of the economy due to growth. For instance, the transition of an industrial society to a service-based one is likely to have a positive effect on its environmental quality. Finally, the technology effect specifies the substitution of obsolete, dirty and inefficient technology by more sophisticated and "cleaner" methods.

Other studies argue that the income elasticity of environmental demand is changing, see e.g. Antle and Heidebrink (1995). As income grows, a higher standard of living is accomplished which might lead individuals to care more about environmental protection. In most societies, this changing attitude will have an impact on actual environmental policy.

Moreover, Torras and Boyce (1998) use sufficiently functioning markets as explanation for the environmental Kuznets curve. Early stage industries are characterized by heavy exploitation of natural resources. This in turn significantly reduces the available stock of resources. Conditioning on an effective market mechanism in pricing resources, a consequence of such exploitation will be rising prices. Higher prices increase pressure to switch to less resource-intensive technologies. Again this leads to a hump-shaped relationship between pollution and income.

Studies like Shafik (1994), Selden and Song (1994) and Grossman and Krueger (1995) report empirical evidence in favor of the EKC. ${ }^{7}$ However, results presented by e.g. Arrow et al. (1995) point out that this finding is not necessarily robust. ${ }^{8}$

\footnotetext{
${ }^{6}$ There are numerous other theories that lead to an EKC. Recent modeling setups involve, e.g. total factor productivity (see Chimeli and Braden (2005)) and second-best fiscal policy frameworks (see Cassou and Hamilton (2004)).

${ }^{7}$ For a detailed survey of theoretical and empirical studies dealing with the EKC, we refer to Dinda (2004).

${ }^{8}$ Some authors propose an inverted N-shaped or even a N-shaped relationship. See, e.g. Holtz-
} 
We use the level, squared and cubic transformations of (the log of) real GDP per capita ( $L G D P P C, L G D P P C^{2}, L G D P P C^{3}$ ) to test the EKC theory. ${ }^{9}$

According to, e.g. Cole (2004), trade may reduce pollution emissions due to greater competitive pressure or "greater access to 'greener' production technologies" (p. 79). ${ }^{10}$ For that reason we introduce the variable TRADE, representing trade intensity, in our analysis. This variable is defined as the ratio of imports plus exports over GDP. Often the effect of trade is also disaggregated into three components: a scale effect, a technique effect, and a composition effect.

The scale effect refers to the fact that trade enlarges the sales markets which presumably increases production which in turn increases pollution. The technique effect relates to the trade induced changes of the production technology. The composition effect stems from changes in production of an economy caused by specialization. In case the latter is associated with cross-country differences in environmental regulation, it is commonly labeled the pollution haven hypothesis $(\mathrm{PHH})$. Countries with a comparative disadvantage in "dirty" production, i.e. with strict environmental regulations, will - according to this hypothesis - outsource pollution-intensive activity. This will increase trade between nations with different comparative advantages (Birdsall and Wheeler (1993), Mani and Wheeler (1998)). ${ }^{11}$

Mainly because micro data is needed to systematically analyze which type of industry has been shifted across border it is quite difficult to falsify the PHH empirically. Hence, most studies end up concluding that their results do not necessarily mean that the PHH exists or not. Of the remaining ones, not many are in favor of the PHH. For instance, Jaffe et al. (1995) and Cole (2004) find no evidence for the existence of the PHH. Since it is virtually impossible to get the adequate micro data that match our otherwise aggregated information, we will also not be in a position to fully address this question. Due to the different natures of the scale, technique and composition effects, the overall impact of trade on the environment is ambiguous. ${ }^{12}$

In a similar vein, international capital transactions might also affect national pollution levels. Following Antweiler et al. (2001) we therefore include inward foreign direct investment as a percentage of GDP (FDIGDP) in our analysis.

Carlsson and Lundström (2003) propose to include real GDP growth (GDPGR). In our panel data setup with annual observations, this variable on the one hand represents the business cycle of a country (time dimension). On the other hand, this variable reflects differences in average growth rates across countries (cross-country

Eakin and Selden (1995), Cole et al. (1997) or Moomaw and Unruh (1997). However, often the additional turning point is out-of-sample.

${ }^{9}$ For a study on the semi-parametric specification of the EKC see Millimet et al. (2003).

${ }^{10}$ This would also be in line with Frankel and Rose (2005) who find that trade tends to reduce pollution even after taking into account potential simultaneity problems. The same authors, however, in case of $\mathrm{CO}_{2}$ emissions point toward a positive relationship which is argued to be due to the global externality feature of that form of pollution.

${ }^{11}$ Ederington et al. (2005) summarize and extend the literature on the effect of environmental regulations on trade flows.

${ }^{12}$ For greater detail, see Grossman and Krueger (1991), Antweiler et al. (2001), Cole and Elliott (2003) and Cole (2004). 
dimension).

The same authors also introduce the index of economic freedom (ECFREE) and the Political Freedom Index (POLFREE) in this line of literature. ${ }^{13}$ They claim that economic freedom leads to a more efficient allocation of resources and therefore to a lower level of emission. ${ }^{14}$ The intuitive reasoning behind POLFREE is that it is easier for people to express their preferences for higher environmental standards in a politically more open system. Other politically motivated variables included in our analysis are a dummy variable measuring whether or not the party of the chief executive has a left-wing orientation ( $L E F T)$, the number of years the chief executive has been in office (YRSOFFC), a dictatorship dummy (DICT), and a second measure of democracy (DEMOC). Our variable LEFT is adapted from Neumayer (2003) and Neumayer (2004) who suggests that despite the traditional political objectives, generally driven by blue-collar workers' interests, a higher degree of sympathy for environmental protection by left-wing governments is possible. ${ }^{15}$ The next variable is suggested by Klick (2002), who argues that the longer a government is in power the less willing it is to enhance pollution controls. He presumes that staying in power has diminishing returns over time. Hence the incentive to stay in power for another day is higher at the first day in power than the day after and so on.

Furthermore, he claims that a dictator might take care of the environment to verify his leading position. Klick argues that because a dictator has a limited number of instruments at hand to remain in power he has strong incentives to invest in environmental protection rather than e.g. schooling. ${ }^{16}$

Contrary to that view Congleton (1992) contends that autocratic countries should have lower environmental standards. He believes that autocratic rulers have a shorter time horizon. Consequently, their incentives to invest in environmental protection are lower. To test his hypothesis Congleton includes the Democracy score from the Polity IV database which we also add to our list of variables as $D E$ MOC. Because of the relatively low correlation between DEMOC and POLFREE and their somewhat different focus we opt to include both measures in our setup. ${ }^{17}$

To check for the influence of the size of the economy many authors introduce a population measure in their models. Following e.g. Borghesi (2000) and Klick (2002), we opt for including (the log of) population density (LPOPDENS). If more

\footnotetext{
${ }^{13}$ We retrieve the indicators for economic and political freedom from, respectively Gwartney et al. (2003) and Freedom House (1999). POLFREE is the average of the two Freedom House indices, i.e. civil liberties and political rights.

${ }^{14}$ Carlsson and Lundström (2003) also decompose the economic freedom index into its underlying components and analyze the elements separately. As noted by de Haan and Sturm (2000), most of the sub-components are highly correlated. Hence, we do not decompose the index in our analysis.

${ }^{15}$ Besides other arguments he puts forth that especially the poor and the working class suffer from environmental degradation.

${ }^{16}$ The variable DICT is calculated out of the Executive Indices of Electoral Competitiveness (EIEC) included in the Database of Political Institutions as collected and described by Beck et al. (1999).

${ }^{17}$ The World Bank classifies the Freedom House indices as belonging to the 'Performance' indicator class measuring the quality of governance (see http://www.worldbank.org/). The Polity IV Democracy score, on the other hand, could be labeled as a 'Process' indicator describing the institutional setup that determines the governance outcome. The democracy score e.g. incorporates constraints on the chief executive that are not accounted for in the Freedom House indices.
} 
people live in a given area the effects of individual pollution aggravates. Thus a high population density leads to more pollution. As a second demographic variable, we use the share of urban population in total population $(U R B A N)$. Cole and Neumayer (2004) argue that means of transports, like cars, buses, etc. are more intensively used in urbanized areas as in rural parts of a country. Moreover, food and other consumer goods have to be transported into cities. Both examples suggest higher levels of pollution in an economy that is more urbanized. On the other hand, citizens living in urbanized areas are directly exposed to industrial pollution and therefore political pressure to reduce pollution might rise (see Damania et al. (2003)).

Torras and Boyce (1998) argue that the distance to the coastline might be negatively related to in particular water pollution. The incentive to keep domestic water clean in case an ocean or sea is nearby to drain the polluted water might be limited. Furthermore, water pollution from other countries without coastal area will eventually have to pass to these regions as well. Therefore, we insert a variable measuring the percentage of land within $100 \mathrm{~km}$ of the sea or a navigable river with ocean access $(C O A S T) .{ }^{18}$

Neumayer (2003) points out that, given that the industry sector is usually regarded as more pollutive than the service sector, the industry share might help to explain the level of pollution. ${ }^{19}$ We introduce such an industrialization measure both in terms of output (INDSHGDP) as well as in terms of labor input (IND$S H E M P)$ in our analysis. Although at first glance it might seem that these two variables quantify the same concept, this need not necessarily be the case. From a theoretical stance, INDSHGDP measures the relative importance of the industry sector in an economy. By controlling for other characteristics INDSHEMP can be interpreted as measuring labor intensity of an industry sector. Especially due to underlying technological changes in the production process these two variables do not have to move in parallel. For instance, assume that a technological shock increases the productivity per worker. If employment remains unaltered then INDSHEMP is unaffected. However, INDSHGDP rises in this case. This theoretical reason is reinforced by a rather low correlation coefficient of 0.375 between these two measures (see Table A-3). INDSHEMP may also account for the pressure from industrial workers for lower regulations and hence should lead to a higher level of pollution (see Damania et al. (2003)).

Besides the degree of the industrialization, the composition of a country's energy sector might play an important role. To check if it matters how energy is produced, we include the share of electricity production from oil sources in total electricity production (OILENERGY), slightly adapting Neumayer (2003). ${ }^{20}$

Following Neumayer (2003), we also include the amount of commercial energy

\footnotetext{
${ }^{18}$ The variable COAST is taken from Gallup et al. (1999).

${ }^{19}$ See also Torras and Boyce (1998), Carlsson and Lundström (2003) and Cole and Neumayer (2004).

${ }^{20}$ Obviously oil is not the only energy source used in electricity production. However, data limitations force us to restrict our attention to oil.
} 
used to produce one $\$$ of output ( $E N E R G Y G D P$ ). Conditioning on the characteristics of an economy, this variable proxies for the level of energy efficiency in the production process. The more energy efficient an economy produces its goods and services, the less polluted it should be. In case of ENERGYGDP this means: The higher ENERGYGDP the less energy efficient is the production process and thus the more waste it creates.

As a final economic structure variable, we take (the log of) the use of fertilizer (LFERT) into our list of potential explanatory variables. Cole and Elliott (2003) suggest that higher fertilizer consumption increases the level of water pollution. Besides the straightforward effect that fertilizer has on water pollution it seems reasonable to assume that it may as well help explain the level of air pollution. First, one can interpret this variable as a measure of the general attitude toward environmental protection. For instance, in an economy that heavily uses fertilizer the awareness level of carbon dioxide produced by cars, by burning oil, etc. might not be very high either. Another aspect, which seems predominant in low income countries, is that fertilizer is relatively easy and cheap to produce but has a relatively polluting production process. The presence of these "dirty" industries increases both water and air pollution.

A prominent view is that if income is unequally distributed the median voter is likely to be less endowed with capital and thus would favor a higher rate of capital taxation (see Alesina and Rodrik (1994)). If she receives her income from basic manufacturing, i.e. the relative dirty sector in the economy, then income inequality will be associated with greater deterioration; it would reduce the demand for environmental regulation and increase pollution. The same outcome but a different line of argumentation is proposed by Torras and Boyce (1998). High income inhabitants (asset owners) are likely to have greater economic but also political "power". ${ }^{21}$ Their asset ownership yields a net gain of increased economic activity, i.e. the costs (pollution) are outweighed by the benefits (capital income). Since their vigilance to pursue environmental protection is somewhat muted, they favor actions which allow them to increase or at least hold their level of economic activity constant. As a result the socially optimal level of environmental quality is not reached.

According to McAusland (2003) the effect of inequality on the environment depends on the ownership distribution behind inequality. In case large but poor parts of society own shares of firms using clean technologies, more inequality might actually lead to an improvement of the environment. ${ }^{22}$

A similar, but less ambiguous result is developed by Gassebner et al. (2006). They show theoretically and empirically that the declining economic significance of

\footnotetext{
${ }^{21}$ In their paper they comment on the political influence of a secretary and a CEO. They state that it is unlikely that the secretary has more political power.

${ }^{22}$ However, the overall sign of the relationship also depends upon the terms of trade effect. The author assumes that in a closed economy pollution policy would make dirty goods more expensive and hence alter the terms of trade between dirty and clean goods. A majority of the poor owning clean capacities would hence prefer a less stringent policy. Nevertheless, assuming an open economy facing fixed world prices, the same majority would prefer more stringent policies, because the terms of trade would then not alter.
} 
the industrial sector, associated with falling industrial incomes and a lower political weight of blue-collar workers tends to increase environmental regulation and thereby leads to less pollution.

Hence, we introduce the variable INEQUAL. It is taken from the University of Texas Inequality Project (UTIP (2001)) and is based on the United Nations International Development Organization's (UNIDO) database of payments. The inequality measure is derived from the between-groups component of the Theil's $\mathrm{T}$ statistic. ${ }^{23}$

Pollution might also be related to the level of education in a country. Torras and Boyce (1998) as well as Klick (2002) include measures of education as control variables in their respective setup. In the spirit of Lipset (1959), who argues that education is at least a necessary condition for democracy, higher education can be considered a prerequisite for higher demand of a clean environment. We include both primary education (PRIMEDU) and the illiteracy rate among adults (ILLIT) in our setup.

This leaves us with a list of 23 explanatory variables covering in total close to 200 countries over the period 1960-2001. For a complete overview concerning sources and specification of the variables we refer to Table A-1.

\section{Model}

We employ (variants) of the so-called Extreme Bounds Analysis (EBA) as suggested by Leamer (1983) and Levine and Renelt (1992) to examine which explanatory variables are robustly related to our dependent variables. To the best of our knowledge, this has in this line of literature never been done before, although there are some very good reasons to apply this methodology. ${ }^{24}$

The EBA has been widely used in the economic growth literature. The central difficulty in that line of research - which also applies to the research topic of the present paper - is that several different models may all seem reasonable given the data, but yield different conclusions about the parameters of interest. Indeed, a glance at the studies summarized in Table A-2 illustrates this point. The results of these studies sometimes differ substantially. At the same time, most authors do not offer a careful sensitivity analysis to examine how robust their conclusions are.

The EBA can be exemplified as follows. Equations of the following general form are estimated:

$$
Y=\alpha M+\beta F+\gamma Z+u
$$

where $Y$ is the dependent variable; $M$ is a vector of "standard" explanatory variables; $F$ is the variable of interest; $Z$ is a vector of up to three possible additional

\footnotetext{
${ }^{23}$ For details see http://utip.gov.utexas.edu/.

${ }^{24}$ For technical reasons - in particular our unbalanced panel setup - we are unable to use the extension of this approach called Bayesian Averaging of Classical Estimates (BACE) as introduced by Sala-i-Martin et al. (2004).
} 
explanatory variables (following Levine and Renelt (1992)), which according to the literature may be related to the dependent variable; and $u$ is an error term. The extreme bounds test as original proposed by Leamer (1983) for variable $F$ says that if the lower extreme bound for $\beta$-i.e. the lowest value for $\beta$ minus two standard deviations - is negative, while the upper extreme bound for $\beta$-i.e. the highest value for $\beta$ plus two standard deviations - is positive, the variable $F$ is not robustly related to $Y$.

As argued by Temple (2000), it is rare in empirical research that we can say with certainty that some model dominates all other possibilities in all dimensions. In these circumstances, it makes sense to provide information about how sensitive the findings are to alternative modeling choices. Extreme bounds analysis provides a relatively simple means of doing exactly this. Still, the EBA has been criticized in the literature.

Sala-i-Martin (1997) rightly argues that the test applied in the extreme bounds analysis is too strong for any variable to really pass it. If the distribution of the parameter of interest has some positive and some negative support, then one is bound to find one regression for which the estimated coefficient changes sign if enough regressions are run. We will therefore not only report the extreme bounds, but also the percentage of the regressions in which the coefficient of the variable $F$ is statistically different from zero at the $5 \%$-level. Moreover, instead of analyzing just the extreme bounds of the estimates of the coefficient of a particular variable, we follow Sala-i-Martin's (1997) suggestion to analyze the entire distribution. We also report the unweighted parameter estimate of $\beta$ and its standard deviation, as well as the unweighted cumulative distribution function $(\mathrm{CDF}(0))$. The latter shows the fraction of the cumulative distribution function lying on each side of zero. $\operatorname{CDF}(0)$ indicates the larger of the areas under the density function either above or below zero; in other words, regardless of whether this is $\operatorname{CDF}(0)$ or 1-CDF $(0)$. So $\operatorname{CDF}(0)$ will always be a number between 0.5 and 1.0. However, in contrast to Sala-i-Martin, we use the unweighted instead of the weighted $\operatorname{CDF}(0){ }^{25}$

Another objection to EBA is that the initial partition of variables in the $M$ and in the $Z$ vector is likely to be rather arbitrary. Still, as pointed out by Temple (2000), there is no reason why standard model selection procedures (such as testing down from a general specification) cannot be used in advance to identify variables that seem to be particularly relevant. Furthermore, some variables are included in the large majority of studies and are by now rather common in this line of literature. Using a combination of general-to-specific modeling and theoretical considerations, we started with all 23 explanatory variables listed in Table A-1 to set up our baseline

\footnotetext{
${ }^{25}$ Sala-i-Martin (1997) proposes using the (integrated) likelihood to construct a weighted $\mathrm{CDF}(0)$. However, the varying number of observations in the regressions due to missing observations in some of the variables poses a problem. Sturm and de Haan (2002) show that as a result this goodness of fit measure may not be a good indicator of the probability that a model is the true model and the weights constructed in this way are not equivariant for linear transformations in the dependent variable. Hence, changing scales will result in rather different outcomes and conclusions. We therefore restrict our attention to the unweighted version.
} 
model. ${ }^{26}$

In our view, the inclusion of GDP variables in the $M$ vector to capture the EKC argument is evident. Even if one does not believe in the EKC in a strict sense it is rather likely that production of goods and services leads to pollution. In the literature the functional form of the EKC sometimes differs. For that reason, we have checked whether the relationship is linear, quadratic (hump-shaped relationship) or of an even higher order (inverted N-shape relationship). Our results clearly suggest the need of a quadratic term when describing the relationship between GDP and both water and air pollution. Hence, we are able to confirm an inverted U-shaped relationship. Given the better fit to the data when using the squared specification, we leave out the cubic term.

Additionally, efficiency of the production process in general should be a major factor for the pollution level in a given country. This concept is also widely accepted in the literature. A more efficient production leads to less waste and hence to less pollution. The general-to-specific approach confirms that energy use (EN$E R G Y G D P$ ) indeed has a strong relationship to either form of pollution. Besides the two GDP variables capturing the EKC, ENERGYGDP therefore completes our baseline model, i.e. our set of $M$ variables mentioned in equation (1).

\section{Results}

Utilizing the EBA we are able to minimize the problem of model uncertainty. However, since there are further critical aspects of this method that may be voiced, we will not only discuss and interpret the significant variables, but also qualify our results in this section.

An important step in qualifying the robustness of our estimation output is to discuss causality and endogeneity aspects. So far, no study in the field of the EKC that we are aware of dwells upon this topic. In our view, an effective way in evaluating the relevance of this problem is to utilize lagged explanatory variables. ${ }^{27}$ When we run the EBA employing lagged variables the results remain virtually unchanged as compared to the outcomes with contemporaneous variables. ${ }^{28}$ Calculated correlation coefficients between the results of the two variable sets are around 95 to 99 percent. In addition, on average the significance of the proposed variables when using lagged versions increases. This leads us to conclude that endogeneity is in our case not of major importance and that causality points in the desired direction. We decide to base the discussion of the results on the estimates using lagged variables. ${ }^{29}$

\footnotetext{
${ }^{26}$ Another minor restriction which one has to bear in mind is that the baseline specification should include as many observations as possible in order to have reasonable sample sizes when testing the remainder of the variables.

${ }^{27}$ If coefficients would alter substantially due to using lags instead of contemporaneous versions, this would indicate biased estimates in pursuance of endogeneity. In addition, this would place doubts pertaining to causality.

${ }^{28}$ There is one noteworthy exception, however. The $\operatorname{CDF}(0)$ value of lagged GDP growth in the $\mathrm{CO}_{2}$ case is higher.

${ }^{29}$ Results using contemporaneous variables are available from the authors upon request.
} 
Table 1: Specification tests for the base models

\begin{tabular}{lcc}
\hline & $\mathrm{BOD}$ & $\mathrm{CO}_{2}$ \\
\hline \hline $\begin{array}{l}\text { Hausman Test }\left(\chi^{2}\right) \\
\text { (country and time) }\end{array}$ & 2.01 & 5.12 \\
& $(0.57)$ & $(0.16)$ \\
& & \\
F-Test for random effects: & & \\
Country-specific & 67.07 & 135.80 \\
& $(0.00)$ & $(0.00)$ \\
Time-specific & 8.73 & 3.47 \\
& $(0.00)$ & $(0.00)$ \\
Both dimensions & 57.59 & 104.58 \\
& $(0.00)$ & $(0.00)$ \\
& & \\
LR-Test & 2926.74 & 5992.97 \\
(country and time) & $(0.00)$ & $(0.00)$ \\
\hline
\end{tabular}

Note: p-values are in parentheses.

Testing Hypothesis: Hausman Test $\mathrm{H}_{0}$ : random effects, $\mathrm{H}_{1}$ : fixed effects; F-Test $\mathrm{H}_{0}$ : pooled OLS, $\mathrm{H}_{1}$ : random specific effect; $L R$-Test $\mathrm{H}_{0}$ : pooled OLS, $\mathrm{H}_{1}$ : fixed effects.

Further robustness tests on our EBA results will be presented at the end of this section.

Throughout, we conduct specification tests to decide whether or not, and if so, how to correct for country-specific as well as time-specific effects. Table 1 shows that for our baseline model a random effects model including both country- and time-specific effects is preferred on statistical grounds. In general, this conclusion also holds for other models.

To check the robustness of this baseline model with respect to model specification all combinations of up to three variables out of the remaining 19 variables are added. The top part of Tables 2 and 3 summarize the results of these of 1,159 combinations for the baseline model. ${ }^{30}$ The variables are sorted according to the estimated $\mathrm{CDF}(0)$ values. All three variables are highly significant according to the $\operatorname{CDF}(0)$ criterion of Sala-i-Martin (1997) in both tables, i.e. the baseline model works extremely well. In case of $\mathrm{CO}_{2}$, the lower and upper extreme bounds have the same sign, i.e. these variables even pass the extreme EBA test of Leamer (1983) and Levine and Renelt (1992).

The EBA results for the baseline model strengthen the relevance of the EKC hypothesis. The negative coefficient of squared GDP per capita implies that there indeed exists an inverted U-shape relationship between per capita GDP and both pollution variables. ${ }^{31}$

Whether or not the turning point of the inverted U-shape is within sample is, especially from a policy analysis perspective, an important question. For that reason, we calculate the implied turning points of the EKC for each of the 1,159 regressions

\footnotetext{
${ }^{30}$ Note that the results for $\mathrm{SO}_{2}$ are presented in Table A-6.

${ }^{31}$ Throughout this paper when interpreting the effect of an explanatory variable we are, due to our setup, speaking of lagged effects. However, in order to enhance readability, we do not explicitly state this every time.
} 
Table 2: Extreme Bounds Analysis with lagged explanatory variables Dependent variable: Water pollution $(L B O D P C)$

\begin{tabular}{|c|c|c|c|c|c|c|c|}
\hline Variable & $\begin{array}{r}\text { Lower } \\
\text { Bound }\end{array}$ & $\begin{array}{l}\text { Upper } \\
\text { Bound }\end{array}$ & \%Sign. & $\begin{array}{r}\text { Unwght. } \\
\text { CDF(0) }\end{array}$ & $\begin{array}{c}\text { Unwght. } \\
\beta \\
\end{array}$ & $\begin{array}{r}\text { Std. } \\
\text { Error }\end{array}$ & $\begin{array}{r}\text { Impact } \\
\text { Rank }\end{array}$ \\
\hline \multicolumn{8}{|l|}{ 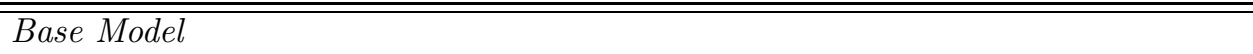 } \\
\hline LGDPPC1 & -0.131 & 7.304 & 99.91 & 1.0000 & 3.358 & 0.316 & - \\
\hline LGDPPCSQ1 & -0.398 & 0.043 & 99.83 & 0.9999 & -0.173 & 0.019 & - \\
\hline ENERGYGDP1 & -0.039 & 1.534 & 99.83 & 0.9998 & 0.629 & 0.070 & 1 \\
\hline \multicolumn{8}{|l|}{ Extended Model } \\
\hline INEQUAL1 & -0.055 & 0.004 & 99.70 & 0.9997 & -0.025 & 0.003 & 2 \\
\hline INDSHGDP1 & -0.017 & 0.045 & 99.70 & 0.9994 & 0.017 & 0.003 & 4 \\
\hline INDSHEMP1 & -0.010 & 0.038 & 98.18 & 0.9985 & 0.019 & 0.003 & 3 \\
\hline LFERT1 & -0.109 & 0.227 & 77.61 & 0.9661 & 0.063 & 0.024 & 6 \\
\hline COAST & -0.042 & 0.022 & 75.08 & 0.9589 & 0.006 & 0.002 & - \\
\hline LEFT1 & -0.174 & 0.204 & 41.95 & 0.9034 & 0.042 & 0.027 & 13 \\
\hline DEMOC1 & -0.029 & 0.069 & 42.15 & 0.8954 & 0.010 & 0.006 & 9 \\
\hline DICT1 & -0.354 & 0.157 & 36.17 & 0.8515 & -0.065 & 0.039 & 10 \\
\hline YRSOFFC1 & -0.009 & 0.023 & 36.58 & 0.8510 & 0.003 & 0.002 & 11 \\
\hline URBAN1 & -0.025 & 0.049 & 57.55 & 0.7954 & 0.009 & 0.003 & 5 \\
\hline ECFREE1 & -0.130 & 0.183 & 7.40 & 0.7902 & 0.029 & 0.031 & 8 \\
\hline ILLIT1 & -0.043 & 0.020 & 43.36 & 0.6928 & -0.004 & 0.003 & 7 \\
\hline OILENERGY1 & -0.009 & 0.006 & 12.16 & 0.6567 & 0.000 & 0.001 & 16 \\
\hline LPOPDENS1 & -0.499 & 1.310 & 48.83 & 0.6509 & 0.068 & 0.062 & 12 \\
\hline TRADE1 & -0.004 & 0.008 & 10.03 & 0.6461 & 0.000 & 0.001 & 15 \\
\hline GDPGR1 & -0.028 & 0.010 & 6.38 & 0.5843 & -0.001 & 0.002 & 14 \\
\hline POLFREE1 & -0.071 & 0.095 & 18.95 & 0.5783 & 0.004 & 0.011 & 17 \\
\hline FDIGDP1 & -0.056 & 0.071 & 5.07 & 0.5688 & 0.000 & 0.006 & 19 \\
\hline PRIMEDU1 & -0.018 & 0.015 & 9.73 & 0.5671 & 0.000 & 0.002 & 18 \\
\hline
\end{tabular}

Note: Results based on 1,159 (base model) and 987 (extended model) regressions respectively using country- and time-specific random effects. '\%Sign.' refers to the percentage of regressions in which the respective variable is significant at a $5 \%$ significance level. 'Impact Rank' lists the variables in descending order according to the impact resulting from a shock of one standard deviation. The standard deviation is calculated after correcting for country- and time-specific effects.

of both baseline models. Figure 1 shows the histograms of these calculated turning points; Table 4 reports the descriptive statistics. In line with Cole (2004), we find the average turning point for $B O D$ - with a value of roughly 18,000 constant 1995 US $\$$ per capita - to be in-sample, while that for $C_{2}$ - with an average of 120,000 constant 1995 US $\$$ per capita - to be out-of-sample. It seems that, since water pollution has somewhat less of an international public good character and becomes apparent much sooner than $\mathrm{CO}_{2}$ emissions, actions against water pollution are taken at a clearly earlier stage of economic development.

When looking at the sign of the third variable in our basic model no surprises arise. The positive sign of ENERGYGDP shows that a production technique that is energy inefficient leads to more pollution.

In the next step, each of the remaining 19 variables is added to the baseline model one at a time to take the function of the $F$ variable in equation (1). The other 18 variables are then - in 987 combinations - used to check the robustness of 
Table 3: Extreme Bounds Analysis with lagged explanatory variables Dependent variable: Air pollution $\left(\mathrm{LCO}_{2} \mathrm{PC}\right)$

\begin{tabular}{|c|c|c|c|c|c|c|c|}
\hline Variable & $\begin{array}{l}\text { Lower } \\
\text { Bound }\end{array}$ & $\begin{array}{l}\text { Upper } \\
\text { Bound }\end{array}$ & \%Sign. & $\begin{array}{r}\text { Unwght. } \\
\text { CDF(0) }\end{array}$ & $\begin{array}{c}\text { Unwght. } \\
\beta\end{array}$ & $\begin{array}{r}\text { Std. } \\
\text { Error }\end{array}$ & $\begin{array}{r}\text { Impact } \\
\text { Rank }\end{array}$ \\
\hline \multicolumn{8}{|l|}{ Base Model } \\
\hline LGDPPC1 & 0.881 & 5.761 & 100.00 & 1.0000 & 3.197 & 0.191 & - \\
\hline LGDPPCSQ1 & -0.295 & -0.006 & 100.00 & 1.0000 & -0.145 & 0.012 & - \\
\hline ENERGYGDP1 & 0.247 & 1.392 & 100.00 & 1.0000 & 0.606 & 0.044 & 1 \\
\hline \multicolumn{8}{|l|}{ Extended Model } \\
\hline LFERT1 & -0.064 & 0.185 & 96.45 & 0.9958 & 0.084 & 0.015 & 2 \\
\hline INDSHEMP1 & -0.034 & 0.031 & 95.54 & 0.9918 & 0.012 & 0.003 & 3 \\
\hline TRADE1 & -0.001 & 0.009 & 86.22 & 0.9899 & 0.002 & 0.000 & 7 \\
\hline DICT1 & -0.329 & 0.117 & 85.71 & 0.9840 & -0.095 & 0.028 & 8 \\
\hline GDPGR1 & -0.012 & 0.031 & 67.27 & 0.9477 & 0.003 & 0.001 & 11 \\
\hline INEQUAL1 & -0.071 & 0.011 & 74.37 & 0.9465 & -0.007 & 0.003 & 9 \\
\hline LPOPDENS1 & -0.166 & 0.749 & 79.74 & 0.9433 & 0.166 & 0.046 & 4 \\
\hline LEFT1 & -0.105 & 0.176 & 57.24 & 0.8952 & 0.039 & 0.020 & 14 \\
\hline FDIGDP1 & -0.038 & 0.066 & 64.84 & 0.8779 & 0.009 & 0.004 & 5 \\
\hline URBAN1 & -0.022 & 0.020 & 67.88 & 0.8738 & 0.005 & 0.002 & 6 \\
\hline OILENERGY1 & -0.003 & 0.007 & 34.95 & 0.8635 & 0.001 & 0.001 & 13 \\
\hline INDSHGDP1 & -0.037 & 0.016 & 59.78 & 0.8615 & 0.005 & 0.002 & 12 \\
\hline ILLIT1 & -0.018 & 0.019 & 33.13 & 0.7789 & -0.002 & 0.002 & 10 \\
\hline PRIMEDU1 & -0.008 & 0.011 & 14.79 & 0.7544 & 0.001 & 0.001 & 16 \\
\hline POLFREE1 & -0.077 & 0.078 & 37.18 & 0.7524 & -0.009 & 0.008 & 17 \\
\hline DEMOC1 & -0.037 & 0.048 & 25.63 & 0.7082 & -0.004 & 0.005 & 18 \\
\hline YRSOFFC1 & -0.007 & 0.016 & 21.68 & 0.7061 & 0.001 & 0.001 & 19 \\
\hline ECFREE1 & -0.110 & 0.219 & 2.33 & 0.6487 & 0.012 & 0.022 & 15 \\
\hline COAST & -0.027 & 0.010 & 1.93 & 0.6223 & 0.001 & 0.002 & - \\
\hline
\end{tabular}

Note: Results based on 1,159 (base model) and 987 (extended model) regressions respectively using country- and time-specific random effects. '\%Sign.' refers to the percentage of regressions in which the respective variable is significant at a 5\% significance level. 'Impact Rank' lists the variables in descending order according to the impact resulting from a shock of one standard deviation. The standard deviation is calculated after correcting for country- and time-specific effects.

the coefficient estimates of a particular $F$ variable. The results are presented in the bottom parts of Tables 2 and 3 .

Besides the three variables in the baseline model, these tables show that two additional variables are robustly related to both water $(B O D)$ and air $\left(\mathrm{CO}_{2}\right)$ pollution. These are the industry share as measured by employment (INDSHEMP) and fertilizer usage (LFERT). As projected, fertilizer usage (LFERT) increases the level of both water and air pollution. While the theoretical relationship between water pollution and fertilizers is apparent, the estimation results do not reject our reasoning to include $L F E R T$ as an explanatory variable for air pollution as well. Inequality (INEQUAL) is robustly related to water pollution in a negative way. This is broadly in line with Gassebner et al. (2006), who state that inequality, resulting from deindustrialization and translating to a diminishing political power of pollutants, will lead to a cleaner environment.

The EBA results suggest that a higher industry share of employment in total 
Figure 1: Histogram of EKC turning points (in constant 1995 US $\$$ per capita)

$B O D$

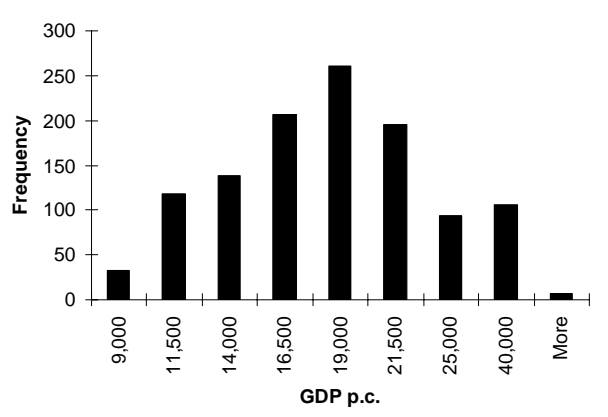

$\mathrm{CO}_{2}$

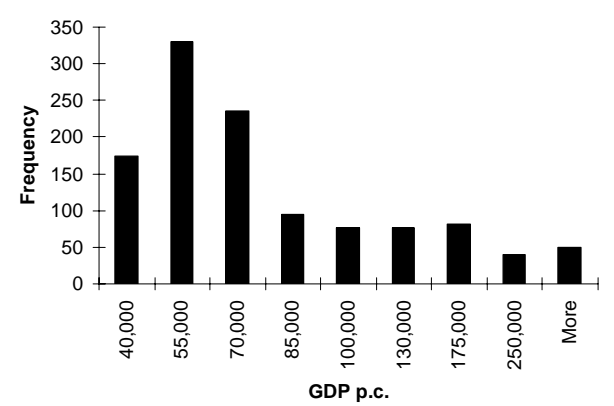

Note: These frequency distributions summarize the results of the EKC turning points of the 1,159 regressions of the base model.

Table 4: Descriptive statistics of the EKC turning points (in constant 1995 US $\$$ per capita)

\begin{tabular}{lrr}
\hline & \multicolumn{1}{c}{$\mathrm{CO}_{2}$} & \multicolumn{1}{c}{$\mathrm{BOD}$} \\
\hline \hline Average turning point & 121,564 & 17,857 \\
Median turning point & 58,513 & 17,431 \\
Turning point of avg. coeff.* & 61,771 & 16,281 \\
& & \\
Standard deviation & 700,915 & 5,895 \\
Kurtosis & 1024.41 & 5.75 \\
Skewness & 31.12 & 1.49 \\
\hline
\end{tabular}

Note: Results are based on the coefficients of the 1,159 regressions of the base model.

* Represents the result when first calculating the average of the 1,159 coefficients and then calculating the turning point.

employment induces more political pressure against pro-environmental policies. In case we control for the industry share in GDP, the same variable can be interpreted as showing that a more labor-intensive industry leads to both, more water and air pollution. Possibly, a labor-intensive industrial sector is less efficient and therefore produces more waste.

Other similarities between $\mathrm{BOD}$ and $\mathrm{CO}_{2}$ are that quite a number of variables do not feature a robust relationship with the dependent variables. This list includes both education variables, i.e. the illiteracy rate (ILLIT) as well as primary education (PRIMEDU). Also most political-institutional variables, which recently received special attention in the literature, belong to this category. Democracy (DEMOC), economic (ECFREE) and political freedom (POLFREE), the duration of the executive being in office (YRSOFFC) and the left-wing dummy all have no robust impact on either of our two pollution variables.

There are some notable differences between the two pollution variables with respect to the significance of some of the remaining explanatory variables. The only remaining political-institutional variable, i.e. the dictatorship dummy $(D I C T)$, 
exhibits a relatively robust negative relationship with $\mathrm{CO}_{2}$ but not with $\mathrm{BOD}$. This results appears at least partly to be in line with Klick (2002), who claims that improving environmental quality may be a powerful and effective way to bribe the population and secure a dictator's tenure. ${ }^{32}$

Second, the industry share of GDP (INDSHGDP) is robustly related to an increase in $B O D$, but not in case of $\mathrm{CO}_{2}$. Apparently, the more important the industrial sector is in an economy, the higher the level of water pollution will be. This result even holds after controlling for the industry share in employment (INDSHEMP).

Third, international trade $(T R A D E)$ is almost never significantly related to water pollution, whereas for $\mathrm{CO}_{2}$ pollution it has a $\mathrm{CDF}(0)$ of 0.99 . Our results suggest that trade rather appears to have a negative effect on air quality. Hence, of the three components underlying the effect of trade, the technique effect - which basically refers to the increased availability of "greener" technologies and supported by, e.g. Cole (2004) - cannot be dominant, i.e. it appears to be overshadowed by either the scale or the composition effect, or both.

Our result with respect to TRADE might therefore be interpreted as indirect evidence in favor of a significant composition effect or even the pollution haven hypothesis. International trade based upon comparative advantages in the stringency of environmental regulation would - according to the latter theory - indeed, ceteris paribus, increase the worldwide level of pollution. ${ }^{33}$

Unlike TRADE, foreign direct investment (FDIGDP) does not appear to play a robust role with respect to either form of pollution.

The results concerning population density (LPOPDENS) suggest to some extent that more inhabitants per square kilometer lower a country's air quality, but do not necessarily affect water quality. Urbanization $(U R B A N)$ fails to meet the criterion of a robust variable in both cases. The demographic factor which significantly helps to explain water pollution is a country's share of land in proximity to an ocean or navigable river with ocean access $(C O A S T)$. As to be expected, this variable bears no robust relationship with air pollution.

Besides its significance, the impact of a variable is of importance. In Tables 2 and 3 the column "Impact Rank" refers to the ranking according to the impact of a shock of one standard deviation of the respective variable on the level of pollution. ${ }^{34}$ Due to the non-linearity of $L G D P P C$ and $L G D P P C^{2}$ both variables are excluded from the ranking. COAST is also excluded from the ranking since it represents a country-specific constant. The most important result is that energy efficiency is not only extremely robust, but also has the largest impact on pollution. In all

\footnotetext{
${ }^{32}$ For instance, bribing the population with money would increase the likelihood of revolts, since they may buy weapons, start propaganda campaigns, etc.

${ }^{33}$ According to this theory, some individual (especially developed) countries would see some improvement due to trade. However, this would not outweigh the increased pollution levels in the remaining (mainly developing) countries.

${ }^{34}$ To avoid country- and time-specific effects all variables are de-meaned separately for each country in both dimensions before calculating its standard deviation. Failing to do so would overestimate the effect of a respective variable; more importantly in our case since we are only interested in the ranking it would bias the estimated impact and thereby the ranking.
} 
specifications it is ranked first with respect to its impact on both pollution measures. A second finding is that - as expected - the more robust variables are in general also the ones that have the higher impact.

One of the objections against EBA is that all regressions get an equal weight, suggesting that misspecified equations are given too much consideration in the analysis. This might, in a worst case scenario, bias the outcome. In order to minimize this danger, we employ White's (1980) test for general heteroscedasticity and the Ramsey RESET test of functional form (see Ramsey (1969), Granger and Terasvirta (1993), and Lee et al. (1993)) to exclude all potentially problematic specifications. ${ }^{35}$ The White test is the most general test for heteroscedasticity available, i.e. assumptions about the form of the potential heteroscedasticity must not be made. As a result the test might not only reveal the presence of heteroscedasticity but instead some other form of misspecification (see Thursby (1982) for details). For our particular purpose this is not a shortcoming but a virtue. We are particularly concerned about detecting potentially misspecified equations. ${ }^{36}$

The RESET test is originally designed to discover potential nonlinearities in the specification. Nowadays, it is often believed that the alternatives are not that clear cut, implying that the test may also be used to check for omitted variables as well as some forms of autocorrelation. The test regresses $\hat{u}$ on $\hat{y}^{2}, \hat{y}^{3}$ and a constant. Under the null hypothesis of no specification error the coefficients of $\hat{y}^{2}$ and $\hat{y}^{3}$ are jointly insignificant. Although there is no consensus on what the alternative hypothesis exactly is, rejecting the null hypothesis underlying the RESET test seems to pinpoint serious specification problems.

Running the EBA and controlling for the quality of the residuals by using both of our specification tests leads to the exclusion of approx. $80 \%$ and $60 \%$ of the of the regressions in the $\mathrm{BOD}$ and $\mathrm{CO}_{2}$ cases, respectively. ${ }^{37}$ Nevertheless, our results hardly change at all and the above conclusions remain valid. Most importantly, the variables that exhibit a robust relationship to our pollution measures remain robust whereas no variables additionally meet the $\operatorname{CDF}(0)$ criterion. For sake of brevity, we only report the correlation coefficients between the $\operatorname{CDF}(0) \mathrm{s}$ and the estimated average coefficients of the original and the filtered EBA results in Table 5.

As a backup of our findings, we take the most robust variables according to the EBA and estimate "final" models for both water and air pollution. In the $B O D$ model eight variables meet the criterion of having a $\mathrm{CDF}(0)$ of 0.95 or higher, while in the $\mathrm{CO}_{2}$ model seven variables do. These variables are all included in the respective "final" model. All variables selected according to this criterion are highly significant and have coefficients of the same order of magnitude as reported in the EBA tables. ${ }^{38}$ The results are summarized in Tables 6 and 7 .

\footnotetext{
${ }^{35}$ For both tests we use a cut-off criterion of 5\%-significance.

${ }^{36}$ We choose a variant of White's Test suggested by Wooldridge (2000), where $\hat{u}^{2}$ is regressed on $\hat{y}, \hat{y}^{2}$ and a constant, where $\hat{u}$ is the estimated residual and $\hat{y}$ the fitted dependent variable.

${ }^{37}$ This might seem a lot but the RESET test results show that basically all excluded regressions only suffer from heteroscedasticity. Therefore, all these regression results are still unbiased.

${ }^{38} \mathrm{As}$, of course, this cutoff is rather arbitrary, we also experimented with a cutoff of 0.9 . The conclusions do not depend upon this and in general reflect the findings of the EBA, i.e. the
} 
Table 5: Correlation between original and filtered EBA Results

\begin{tabular}{lrrr}
\hline & CDF(0) & Coeff. & \#Del \\
\hline \hline$B O D$ & 0.95 & 0.76 & 838 \\
$C_{2}$ & 0.84 & 0.89 & 603 \\
\hline
\end{tabular}

Note: ' $\mathrm{CDF}(0)$ ' refers to the correlation between $\mathrm{CDF}(0)$ values while 'Coeff.' stands for the correlation between the respective coefficients. '\#Del' denotes the average number of deleted equations out of 1,159/987 (base/extended model). Equations are deleted in case the RESET and/or the White test indicates potential specification problems on the 5\%-significance level.

Table 6: Final Model - Dependent Variable: Water Pollution $(L B O D P C)$

\begin{tabular}{lrrrrrr}
\hline Sample & \multicolumn{2}{c}{ Full sample } & \multicolumn{2}{c}{ 1990ies } & \multicolumn{2}{c}{ ROW } \\
Variable & Coeff. & Std. E. & Coeff. & Std. E. & Coeff. & Std. E. \\
\hline \hline Constant & $-6.924^{* * *}$ & 1.173 & $-4.888^{* * *}$ & 1.670 & $-6.807^{* * *}$ & 1.409 \\
LGDPPC1 & $1.803^{* * *}$ & 0.283 & $1.430^{* * *}$ & 0.398 & $1.754^{* * *}$ & 0.333 \\
LGDPPCSQ1 & $-0.100^{* * *}$ & 0.016 & $-0.076^{* * *}$ & 0.023 & $-0.097^{* * *}$ & 0.019 \\
ENERGYGDP1 & $0.243^{* * *}$ & 0.072 & $0.225^{* * *}$ & 0.079 & $0.214^{* *}$ & 0.101 \\
INEQUAL1 & $-0.018^{* * *}$ & 0.003 & $-0.022^{* * *}$ & 0.004 & $-0.016^{* * *}$ & 0.004 \\
INDSHGDP1 & $0.010^{* * *}$ & 0.003 & $0.011^{* * *}$ & 0.003 & $0.007^{* *}$ & 0.003 \\
INDSHEMP1 & $0.013^{* * *}$ & 0.002 & $0.010^{* * *}$ & 0.003 & $0.014^{* * *}$ & 0.003 \\
LFERT1 & $0.071^{* * *}$ & 0.020 & 0.018 & 0.028 & $0.081^{* * *}$ & 0.025 \\
COAST & $0.006^{* * *}$ & 0.002 & $0.007^{* * *}$ & 0.002 & $0.005^{* *}$ & 0.002 \\
& & & & & & \\
\hline
\end{tabular}

\begin{tabular}{lrrr}
\hline R-Squared & 0.977 & 0.980 & 0.977 \\
Observations & 611 & 415 & 506 \\
Countries & 81 & 72 & 69 \\
Periods & 19 & 10 & 19 \\
EKC T.P. & 8,405 & 11,477 & 8,213 \\
\hline
\end{tabular}

Note: ${ }^{* *} /{ }^{* * *}$ indicates significance at the $5 \% / 1 \%$-significance level.

'1990ies' uses only the years 1990-1999, 'ROW' (Rest of the World) excludes OECD countries. All estimations include country- and time-specific random effects. 'EKC T.P.' represents the turning point of the EKC in constant 1995 US $\$$ per capita.

Illustrative as of how robust this "final" model is, we also test the sensitivity of these results with respect to changes in the sample. For that purpose, we first split the sample over time, focusing on the 1990s only. Arguably, the world has changed considerably since the 1960s and 1970s. This may also have affected the overall attitude toward pollution. Broadly speaking, our conclusions remain rather similar. The only exceptions are that the effects of fertilizer use (LFERT) on water pollution and dictatorship (DICT) on air pollution both turn insignificant using this sample. Overall, however, our findings concerning the relevance of the variables in use are especially valid even for the most recent time span. In a next step, we split the sample across the country dimension by excluding OECD countries. It can be argued that developed and less developed countries are too different to be included in one setup, which may lead to biases in regression outcomes. Our results, however,

additional variables are generally less significant. 
Table 7: Final Model - Dependent Variable: Air Pollution $\left(\mathrm{LCO}_{2} \mathrm{PC}\right)$

\begin{tabular}{|c|c|c|c|c|c|c|}
\hline \multirow{2}{*}{$\begin{array}{l}\text { Sample } \\
\text { Variable }\end{array}$} & \multicolumn{2}{|c|}{ Full sample } & \multicolumn{2}{|c|}{ 1990ies } & \multicolumn{2}{|c|}{ ROW } \\
\hline & Coeff. & Std. E. & Coeff. & Std. E. & Coeff. & Std. E. \\
\hline Constant & $-11.756^{* * *}$ & 0.795 & $-10.245^{* * *}$ & 0.971 & $-10.245^{* * *}$ & 0.912 \\
\hline LGDPPC1 & $2.152^{* * *}$ & 0.197 & $2.016^{* * *}$ & 0.248 & $1.807^{* * *}$ & 0.225 \\
\hline LGDPPCSQ1 & $-0.086^{* * *}$ & 0.012 & $-0.087^{* * *}$ & 0.015 & $-0.068^{* * *}$ & 0.013 \\
\hline ENERGYGDP1 & $0.438^{* * *}$ & 0.040 & $0.201^{* * *}$ & 0.039 & $0.393^{* * *}$ & 0.045 \\
\hline LFERT1 & $0.086^{* * *}$ & 0.013 & $0.059^{* * *}$ & 0.015 & $0.078^{* * *}$ & 0.015 \\
\hline INDSHEMP1 & $0.010^{* * *}$ & 0.002 & $0.010^{* * *}$ & 0.002 & $0.013^{* * *}$ & 0.002 \\
\hline TRADE1 & $0.002^{* * *}$ & 0.000 & $0.001^{* *}$ & 0.000 & $0.001^{* * *}$ & 0.000 \\
\hline DICT1 & $-0.062^{* *}$ & 0.027 & -0.009 & 0.045 & $-0.072^{* *}$ & 0.032 \\
\hline R-Squared & 0.990 & & 0.995 & & 0.990 & \\
\hline Observations & 997 & & 639 & & 856 & \\
\hline Countries & 111 & & 108 & & 95 & \\
\hline Periods & 17 & & 8 & & 17 & \\
\hline EKC T.P. & 257,345 & & 112,088 & & 601,112 & \\
\hline
\end{tabular}

Note: ${ }^{* *} /{ }^{* * *}$ indicates significance at the $5 \% / 1 \%$-significance level.

'1990ies' uses only the years 1990-1999, 'ROW' (Rest of the World) excludes OECD countries. All estimations include country- and time-specific random effects. 'EKC T.P.' represents the turning point of the EKC in constant 1995 US \$ per capita.

hardly change at all.

It is to note that the estimated turning points for the EKC in these "final" models show some variation across the three different samples. With respect to water pollution, moving to more recent data appears to increase the turning point. The fluctuations in case of air pollution are even bigger. Furthermore, comparing these turning points with those depicted in Figure 1 and Table 4 reveals that including more explanatory variables in a specification has quite an impact on these turning points. Whereas in case of water pollution the turning points in the "final" model fall at the lower end of the distribution shown in the left panel of Figure 1, the opposite is the case for air pollution (right panel of Figure 1). This finding is in line with Harbaugh et al. (2002) who report that the EKC is sensitive to changes in the sample and specification. Nevertheless, in all specifications we do find a very significant hump-shape relationship between the level of development and the level of pollution.

To further test the robustness of our results, we conduct additional EBAs. First - following the above notion -, we split the overall sample along the time dimension. Second, we drop countries with extreme pollution levels from the analysis. Furthermore, we experiment with different baseline models. It turns out that the results reported above hardly change in each of these three cases; neither significance nor coefficient values differ substantially from the results presented above. ${ }^{39}$

In a final robustness check, we examine whether the results depend on the way we

\footnotetext{
${ }^{39}$ The results are available upon request.
} 
deal with country- and time-specific elements. For that, we repeat the EBA analysis using this time either country- and time-specific fixed effects or only country-specific random effects in the underlying specifications. The results of the EBA re-runs are presented in Tables A-4 and A-5 and underscore that also this specification issue in general does not drive the results. ${ }^{40}$

\section{Conclusions}

Environmental quality continues to draw attention both among economists and in the society as a whole. Recently, the discussion in the academic literature has started to focus on political-institutional factors possibly determining pollution levels. However, despite empirical research investigating the interaction of various economic, demographic and political-institutional factors on the one side and pollution on the other, there is no consensus in the literature which of these forces actually matter, thereby casting doubt on the general robustness of published results. The present paper provides an overview and a thorough robustness analysis of these and other determinants of pollution.

A first result - in line with the literature - is that we endorse the existence of an Environmental Kuznets Curve. Using various specifications, a quadratic setup appears dominant, suggesting an inverted U-shaped relationship between prosperity and pollution. Especially in the case of water pollution, the non-linearity of this relationship seems to matter; our estimated average turning point of around 18,000 constant 1995 US $\$$ per capita has already been reached by several countries within our sample. With an estimated average turning point of around 120,000 constant 1995 US $\$$ per capita, this is clearly not the case for air pollution. It is to be noted, however, that these turning points appear to depend upon the chosen specification, especially for $\mathrm{CO}_{2}$ emissions.

Second, a number of variables related to the economic structure of a country matter for its environmental quality. Especially employment-based and to a lesser extent production-based indicators of industrialization are highly significant and have the expected (positive) sign. Furthermore, a variable measuring agricultural intensity, i.e. fertilizer consumption per hectare of arable land, also explains a substantial degree of both air and water pollution levels around the world. A final variable which describes the economic structure of a country is the amount of commercial energy used to produce one unit of GDP. Again both air and water pollution are highly correlated with this structural variable.

Third, openness - as measured by the ratio of trade or foreign direct investment over GDP - is only related to the amount of air pollution in an economy. The more open an economy is, the higher the level of $\mathrm{CO}_{2}$ emission turns out to be. Apparently, the claim that access to "greener" technologies caused by globalization would lead to an improvement of environmental quality is difficult to hold.

\footnotetext{
${ }^{40}$ The only notable exception is that fertilizer use ( $\left.L F E R T\right)$ becomes less robustly related to water pollution once fixed effects in both country and time dimension are included.
} 
Fourth, the type of demographic factors influencing air and water pollution differ substantially. Air pollution to some extent depends on population density. The only demographic factor which helps to explain water pollution is a country's proximity to a sea or an ocean: greater access to international waters increases the level of water pollution. Inequality increases environmental quality. In contrast to the prominent negative association in the literature so far, we confirm model predictions which state that it has indeed beneficial side effects on the environmental quality.

Fifth, recent interest in more politically motivated explanations of environmental quality seems a less promising path. In fact, only our dictatorship dummy appears robustly related to $\mathrm{CO}_{2}$ emissions.

Finally, it is important to point out some limitations of our study. Our focus was to provide an empirical assessment of previously proposed variables. It is well known that focusing on reduced form estimations has the advantage of easy to obtain, clear cut results. However, this comes at the cost of potentially missing some indirect transmission channels. Therefore, further research in this field should on the one hand reconsider and maybe blend some of the theoretical models that lead to the inclusion of some of the variables. On the other hand, it might be worthwhile to use our results and estimate more structurally based models. Also some hypotheses could not be tested due to lack of data. So, even though we believe our work is a major improvement over existing literature, there is still more work to be done. 


\section{References}

Alesina, A. and Rodrik, D. (1994). Distributive politics and economic growth. Quarterly Journal of Economics, 109:465-490.

Antle, J. M. and Heidebrink, G. (1995). Environment and development: Theory and international evidence. Economic Development and Cultural Change, 43(3):603625 .

Antweiler, W., Copeland, B. R., and Taylor, M. S. (2001). Is free trade good for the environment? American Economic Review, 91(4):877-908.

Arrow, K., Bolin, B., Constanza, R., Dasgupta, P., Folke, C., Holling, C. S., Jansson, B.-O., Levin, S., Maler, K.-G., Perrings, C., and Pimental, D. (1995). Economic growth, carrying capacity and the environment. Ecological Economics, 15(2):91-95.

Beck, T., Clarke, G., Groff, A., and Keefer, P. (1999). The Database of Political Institutions. World Bank, Development Research Group, Washington D.C.

Bernauer, T. and Koubi, V. (2004). On the political determinants of environmental quality. CIS Working Paper 2, ETH Zurich.

Birdsall, N. and Wheeler, D. (1993). Trade policy and industrial pollution in Latin America: Where are the pollution havens? Journal of Environment and Development, 2(1):137-149.

Borghesi, S. (2000). Income inequality and the environmental Kuznets curve. Nota di Lavoro 83.2000, Fondazione Eni Enrico Mattei.

Carlsson, F. and Lundström, S. (2003). The effects of economic and political freedom on $\mathrm{CO}_{2}$ emissions. Working Papers in Economics 29, Göteborg University, Department of Economics.

Cassou, S. P. and Hamilton, S. F. (2004). The transition from dirty to clean industries: Optimal fiscal policy and the environmental Kuznets curve. Journal of Environmental Economics and Management, 48(3):1055-1077.

Chimeli, A. B. and Braden, J. B. (2005). Total factor productivity and the environmental Kuznets curve. Journal of Environmental Economics and Management, 49(2):366-380.

Cole, M. A. (2004). Trade, the pollution haven hypothesis and the environmental Kuznets curve: Examining the linkages. Ecological Economics, 48:71-81.

Cole, M. A. and Elliott, R. J. R. (2003). Determining the trade-environment composition effect: The role of capital, labor and environmental regulations. Journal of Environmental Economics and Management, 46:363-383.

Cole, M. A. and Neumayer, E. (2004). Examining the impact of demographic factors on air pollution. Population and Environment, 26(1):5-21.

Cole, M. A., Rayner, A. J., and Bates, J. M. (1997). The environmental Kuznets curve: An empirical analysis. Environment and Development Economics, 2:401416.

Congleton, R. D. (1992). Political institutions and pollution control. Review of Economics and Statistics, 74(3):412-421. 
Damania, R., Fredriksson, P. G., and List, J. A. (2003). Trade liberalization, corruption, and environmental policy formation: theory and evidence. Journal of Environmental Economics and Management, 46(3):490-512.

de Haan, J. and Sturm, J.-E. (2000). On the relationship between economic freedom and economic growth. European Journal of Political Economy, 16:215-241.

Dinda, S. (2004). Environmental Kuznets curve hypothesis: A survey. Ecological Economics, 49:431-455.

Ederington, J., Levinson, A., and Minier, J. (2005). Footloose and pollution-free. Review of Economics and Statistics, 87(1):92-99.

Frankel, J. A. and Rose, A. K. (2005). Is trade good or bad for the environment? Sorting out the causality. Review of Economics and Statistics, 87(1):85-91.

Freedom House (1999). Annual Survey of Freedom Country Scores 1972-1973 to 1998-1999. Freedom House, Washington, D.C.

Gallup, J. L., Sachs, J. D., and Mellinger, A. (1999). Geography and economic development. CID Working Paper 1, Harvard University.

Gassebner, M., Gaston, N., and Lamla, M. (2006). Relief for the environment? The importance of an increasingly unimportant industrial sector. mimeo.

Granger, C. W. J. and Terasvirta, T. (1993). Modelling nonlinear economic relationships. Oxford University Press, Oxford.

Grossman, G. M. and Krueger, A. B. (1991). Environmental impacts of a North American free trade agreement. NBER Working Papers 3914, National Bureau of Economic Research, Inc.

Grossman, G. M. and Krueger, A. B. (1995). Economic growth and the environment. Quarterly Journal of Economics, 110(2):353-377.

Gurr, T., Jaggers, K., and Moore, W. (2003). Polity Handbook IV. University of Colorado Press, Boulder.

Gwartney, J., Lawson, R., and Samida, D. (2003). Economic Freedom in the World: 2003 Annual Report. Fraser Institute, Vancouver.

Harbaugh, W. T., Levinson, A., and Wilson, D. M. (2002). Reexamining the empirical evidence for an environmental Kuznets curve. Review of Economics and Statistics, 84(3):541-551.

Holtz-Eakin, D. and Selden, T. (1995). Stoking the fires? $\mathrm{CO}_{2}$ emissions and economic growth. Journal of Public Economics, 57:85-101.

Jaffe, A. B., Peterson, S. R., Portney, P. R., and Stavins, R. N. (1995). Environmental regulation and the competitiveness of US manufacturing: What does the evidence tell us? Journal of Economic Literature, 33:132-163.

Klick, J. (2002). Autocrats and the environment or it's easy being green. Working Paper Series 02-16, George Mason University.

Kuznets, S. (1955). Economic growth and income inequality. American Economic Review, 1:1-28.

Leamer, E. E. (1983). Let's take the con out of econometrics. American Economic Review, 73:31-43. 
Lee, T. H., White, H., and Granger, C. W. J. (1993). Testing for neglected nonlinearities in time series models: A comparison of neural network methods and alternative tests. Journal of Econometrics, 56:269-290.

Levine, R. and Renelt, D. (1992). A sensitivity analysis of cross-country growth regressions. American Economic Review, 82(4):942-963.

Lipset, S. M. (1959). Some social requisites of democracy: Economic development and political legitimacy. American Political Science Review, 53:69-105.

Mani, M. and Wheeler, D. (1998). In search of pollution havens? Dirty industry in the world economy, 1960-1995. Journal of Environment and Development, $7(3): 215-247$.

McAusland, C. (2003). Voting for pollution policy: the importance of income inequality and openness to trade. Journal of International Economics, 61(2):425451.

Millimet, D. L., List, J. A., and Stengos, T. (2003). The environmental Kuznets curve: Real progress or misspecified models? Review of Economics and Statistics, 85(4):1038-1047.

Moomaw, W. and Unruh, G. (1997). Are environmental Kuznets curves misleading us? The case of $\mathrm{CO}_{2}$ emissions. Environment and Development Economics, 2:451-464.

Neumayer, E. (2003). Are left-wing party strength and corporatism good for the environment? Evidence from panel analysis of air pollution in OECD countries. Ecological Economics, 45:203-220.

Neumayer, E. (2004). The environment, left-wing political orientation and ecological economics. Ecological Economics, 51:167-175.

Ramsey, J. (1969). Tests for specification errors in classical least-squares regression analysis. Journal of the Royal Statistical Society B, 31:350-371.

Sala-i-Martin, X. (1997). I just ran two millions regressions. American Economic Review, 87(2):178-183.

Sala-i-Martin, X., Doppelhofer, G., and Miller, R. I. (2004). Determinants of longterm growth: A Bayesian averaging of classical estimates (BACE) approach. American Economic Review, 94(4):813-835.

Selden, T. M. and Song, D. (1994). Environmental quality and development: Is there a Kuznets curve for air pollution emissions? Journal of Environmental Economics and Management, 27(2):147-162.

Shafik, N. (1994). Economic development and environmental quality: An econometric analysis. Oxford Economic Papers, 46:757-773.

Stern, D. I. (2005). Global sulfur emmissions from 1850 to 2000. Chemosphere, $58: 163-175$.

Stern, D. I. and Common, M. S. (2001). Is there an environmental Kuznets curve for sulfur? Journal of Environmental Economics and Management, 41:162-178.

Sturm, J.-E. and de Haan, J. (2002). How robust is Sala-i-Martin's robustness analysis? mimeo. 
Sturm, J.-E. and de Haan, J. (2005). Determinants of long-term growth: New results applying robust estimation and extreme bounds analysis. Empirical Economics, 30(5):597-617.

Temple, J. (2000). Growth regressions and what the textbooks don't tell you. Bulletin of Economic Research, 52(3):181-205.

Theil, H. (1972). Statistical Decomposition Analysis: with Application to the Social and Administrative Science. North-Holland Publishing Company, Amsterdam.

Thursby, J. (1982). Misspecification, heteroscedasticity, and the Chow and GoldfeldQuandt tests. Review of Economics and Statistics, 64:314-321.

Torras, M. and Boyce, J. K. (1998). Income, inequality, and pollution: A reassessment of the environmental Kuznets curve. Ecological Economics, 25:147-160.

University of Texas Inequality Project (2001). UTIP-UNIDO dataset. http://utip.gov.utexas.edu/data/UTIP_UNIDO2001rv3.xls.

White, H. (1980). A heteroskedasticity-consistent covariance matrix and a direct test for heteroskedasticity. Econometrica, 48:817-838.

Wooldridge, J. M. (2000). Introductory Econometrics: A modern Approach. SouthWestern College Publishing, Cincinnati.

World Bank (2003a). World Development Indicators. World Bank, Washington D.C.

World Bank (2003b). World Development Report. World Bank, Washington D.C.

World Bank (2005). World Development Indicators. World Bank, Washington D.C. 


\section{Appendix}

Table A-1: List of variables and their sources

\begin{tabular}{|c|c|c|c|}
\hline Variable & Sign & Description & Source \\
\hline$\overline{\text { LBODPC }}$ & & $\overline{L \text { Log of } B O D \text { (grams per day) per capita }}$ & "WDI (2003) \\
\hline $\mathrm{LCO}_{2} \mathrm{PC}$ & & Log of $\mathrm{CO}_{2}$ Emissions (metric tons) per capita & WDI (2003) \\
\hline $\mathrm{LSO}_{2} \mathrm{PC}$ & & Log of $\mathrm{SO}_{2}$ Emissions (metric tons) per capita & Stern $(2005)$ \\
\hline COAST* $^{*}$ & + & $\begin{array}{l}\text { Percentage of land within } 100 \mathrm{~km} \text { of ocean or } \\
\text { navigable river with ocean access }\end{array}$ & $\begin{array}{l}\text { Gallup et al. } \\
(1999)\end{array}$ \\
\hline DEMOC & - & $\begin{array}{l}\text { Democracy Score: general openness of politi- } \\
\text { cal institutions }\end{array}$ & $\begin{array}{l}\text { Gurr et al. } \\
(2003)\end{array}$ \\
\hline DICT & $?$ & $\begin{array}{l}\text { Dummy variable for dictatorship (executive } \\
\text { index of electoral competitiveness }<3 \text { ) }\end{array}$ & $\begin{array}{l}\text { Beck et al. } \\
(1999)\end{array}$ \\
\hline ECFREE & - & Fraser Economic Freedom Index & $\begin{array}{l}\text { Gwartney et } \\
\text { al. }(2003)\end{array}$ \\
\hline ENERGYGDP & + & $\begin{array}{l}\text { Commercial energy use (kilogram of oil equiv- } \\
\text { alent)/GDP }\end{array}$ & WDI (2003) \\
\hline FDIGDP & ? & $\begin{array}{l}\text { Net inflows of foreign direct investment (\% of } \\
\text { GDP) }\end{array}$ & $\mathrm{Wl}$ \\
\hline GDPGR & $?$ & GDP growth rate (annual \%) & WDI (2003) \\
\hline ILLIT & + & $\begin{array}{l}\text { Adult illiteracy rate (\% of people ages } 15 \text { and } \\
\text { above) }\end{array}$ & WDI (2003) \\
\hline INDSHEMP & + & $\begin{array}{l}\text { Employment in industry (\% of total employ- } \\
\text { ment) }\end{array}$ & WDI \\
\hline INDS & + & acturi & WI \\
\hline INEQUAL & $?$ & Ind & $\begin{array}{l}\text { UTIP } \\
(2001)\end{array}$ \\
\hline LEFT & $?$ & he party of the chief ex- & $\begin{array}{l}\text { Beck et al. } \\
(1999)\end{array}$ \\
\hline LFERT & + & $\begin{array}{l}\text { Log of fertilizer use (100 grams per hectare of } \\
\text { arable land) }\end{array}$ & WDI (2003) \\
\hline LGDPPC & + & Log of GDP (constant 1995 US \$) per capita & WDI (2003) \\
\hline LGDPPCSQ & - & Squared log of real GDP per capita & WDI (2003) \\
\hline LGDPPCCB & ? & Cubic log of real GDP per capita & WDI (2003) \\
\hline & + & & 2003) \\
\hline OILENER & + & $\begin{array}{l}\text { Electricity production from oil sources ( } \% \text { of } \\
\text { total) }\end{array}$ & WDI (2003) \\
\hline POLFREE & - & Average of the & FHI (1999) \\
\hline PRIMEDU & - & $\begin{array}{l}\text { Gross primary school enrollment (\% of corre- } \\
\text { sponding age group) }\end{array}$ & WDI (2003) \\
\hline & ? & port + export)/GDP) & WD \\
\hline & ? & & WDI (2003) \\
\hline YRSOFFC & + & $\begin{array}{l}\text { Number of years chief executive has been in } \\
\text { office }\end{array}$ & $\begin{array}{l}\text { Beck et al. } \\
(1999)\end{array}$ \\
\hline
\end{tabular}

Note: Variables are sorted alphabetically. 'Sign' refers to the expected sign: '+/-' denotes a positive/negative relation according to the literature while '?' denotes an a priori ambiguous effect.

*The data for the variable COAST is available only for 1995 . We assume this variable to be constant over our estimation period 1960-2001. 


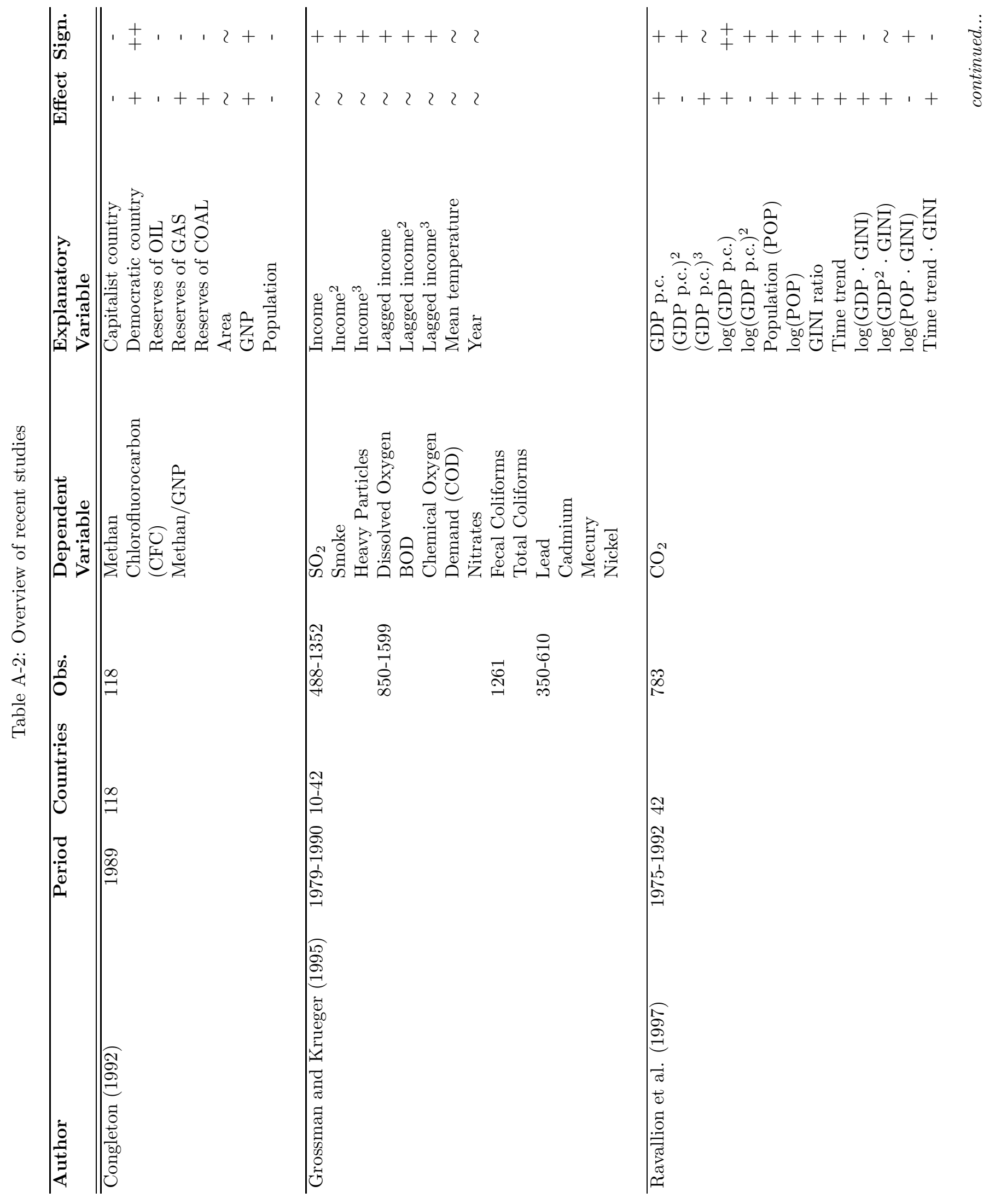




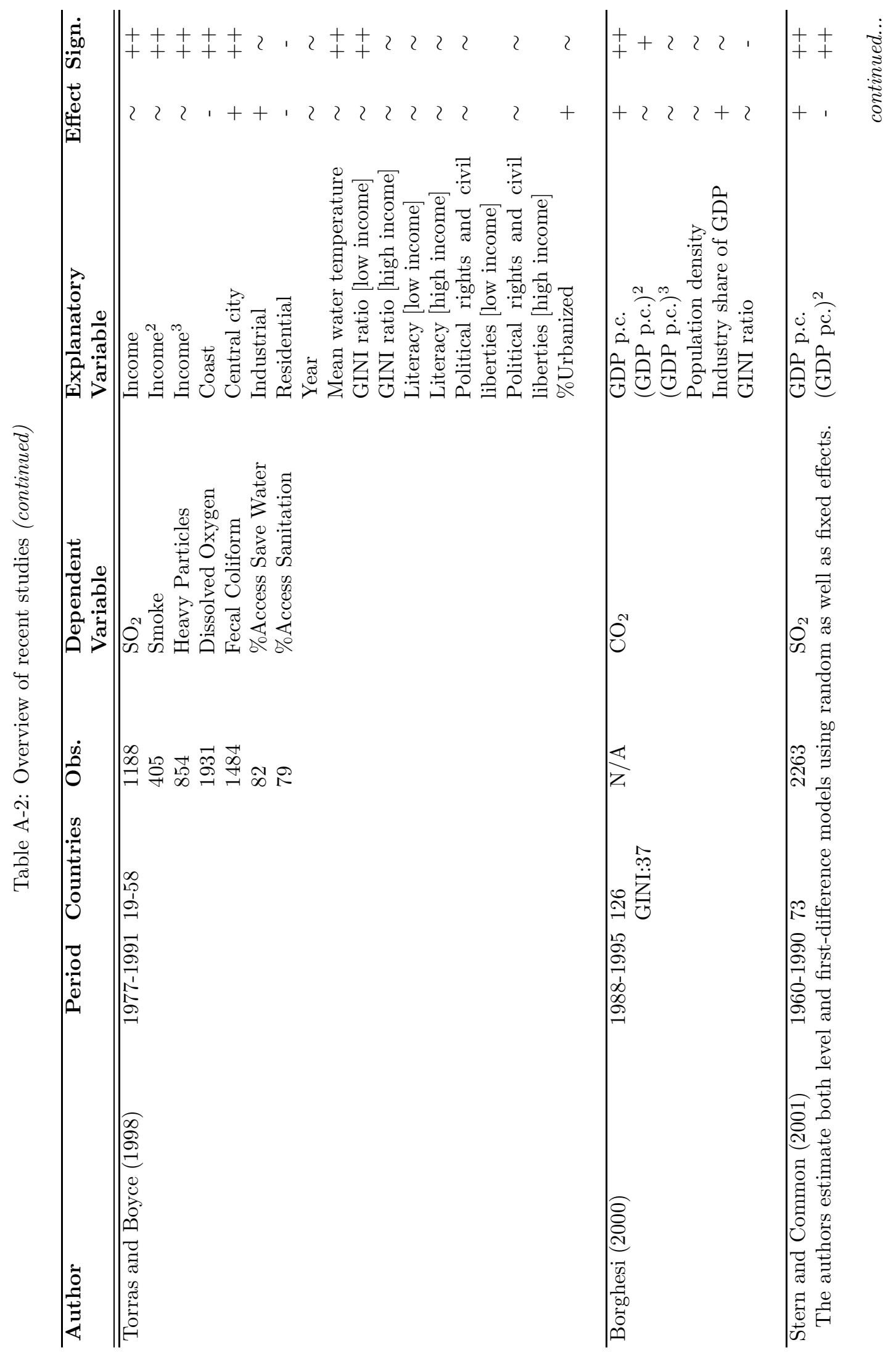




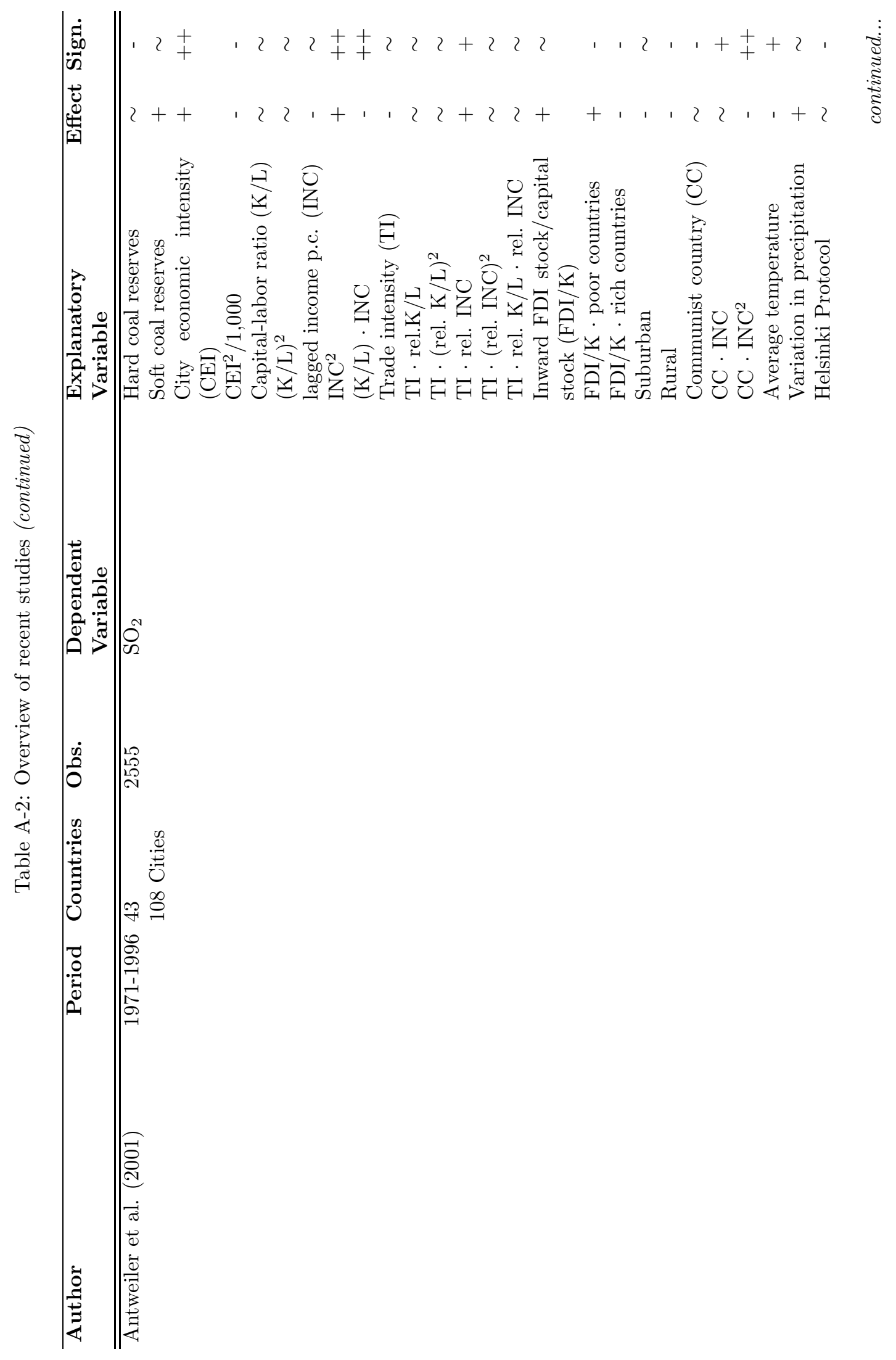




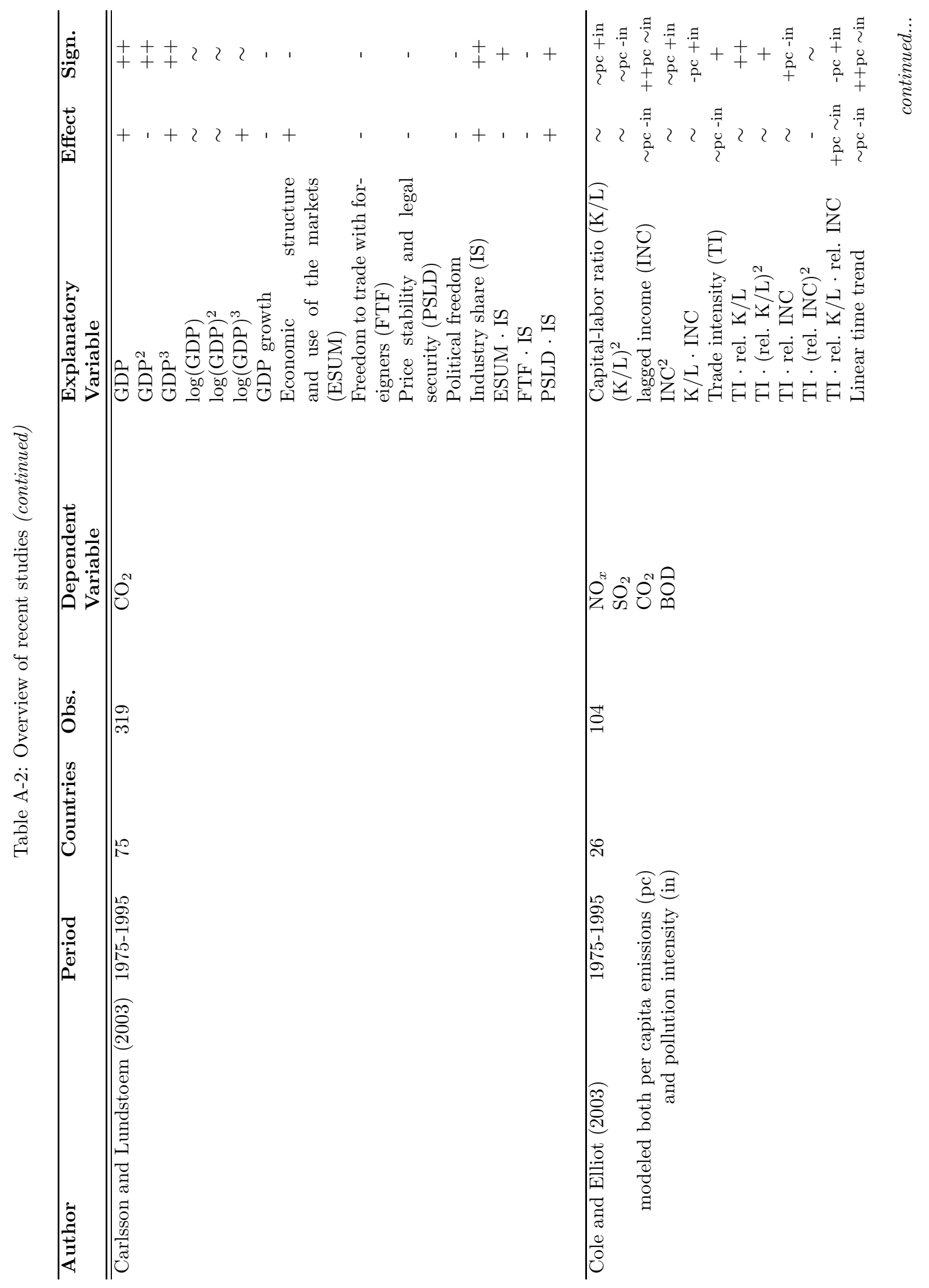




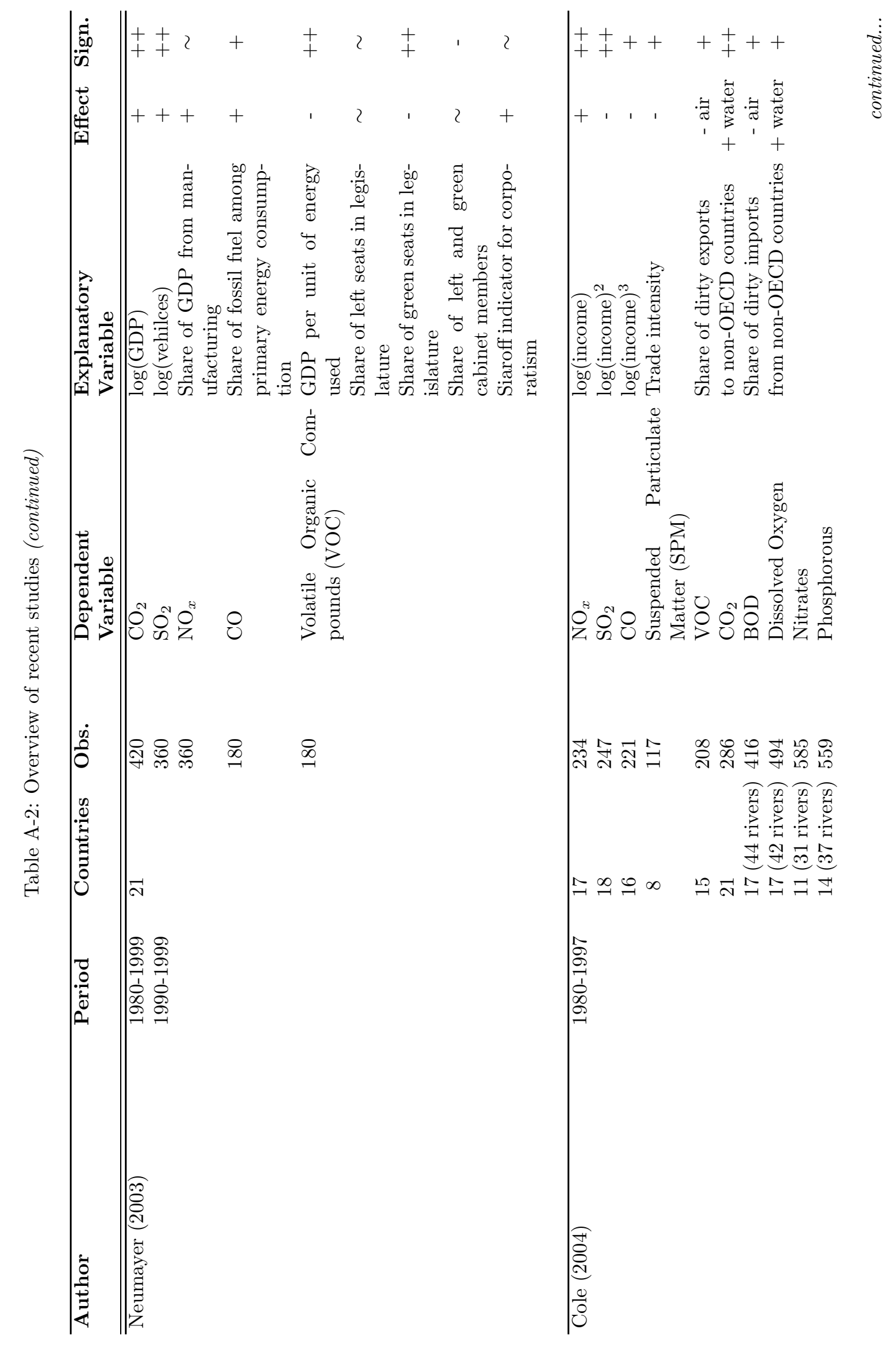




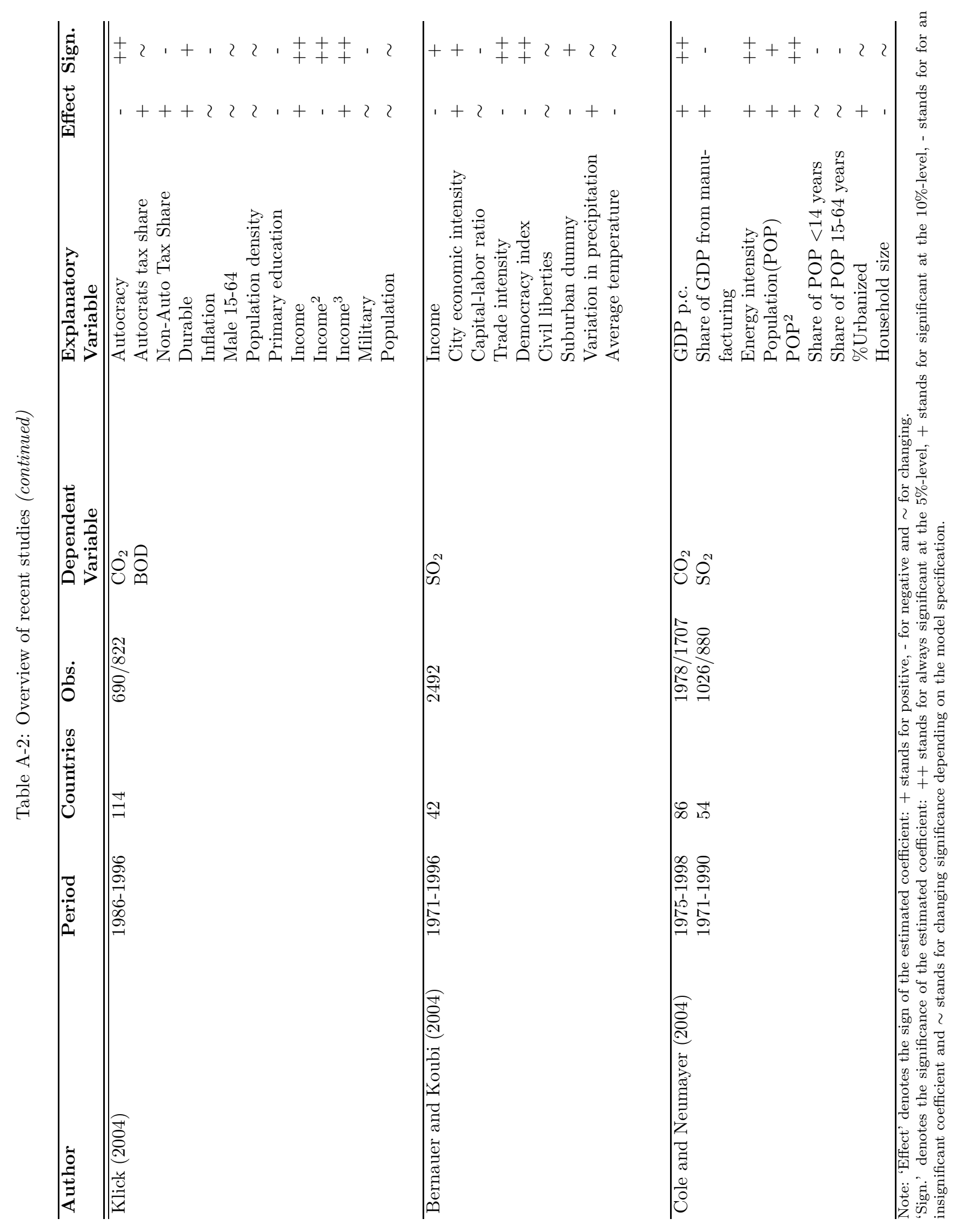




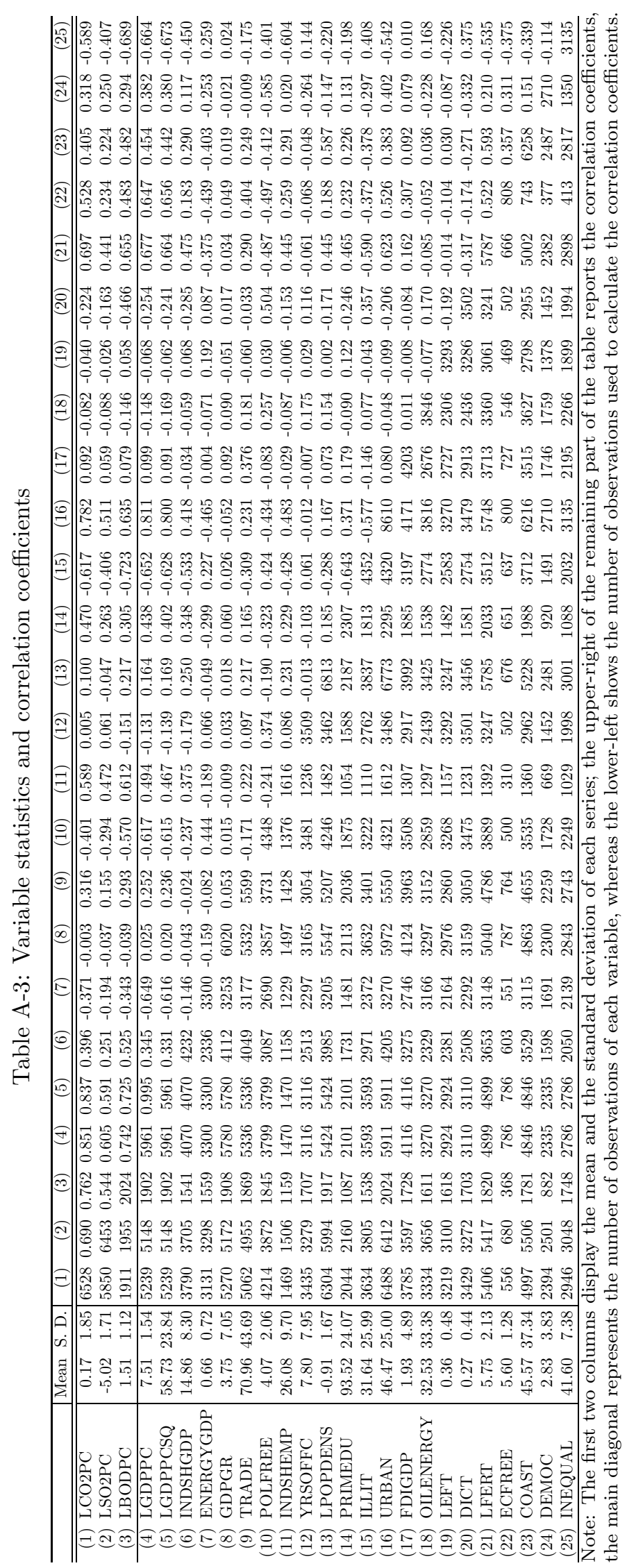




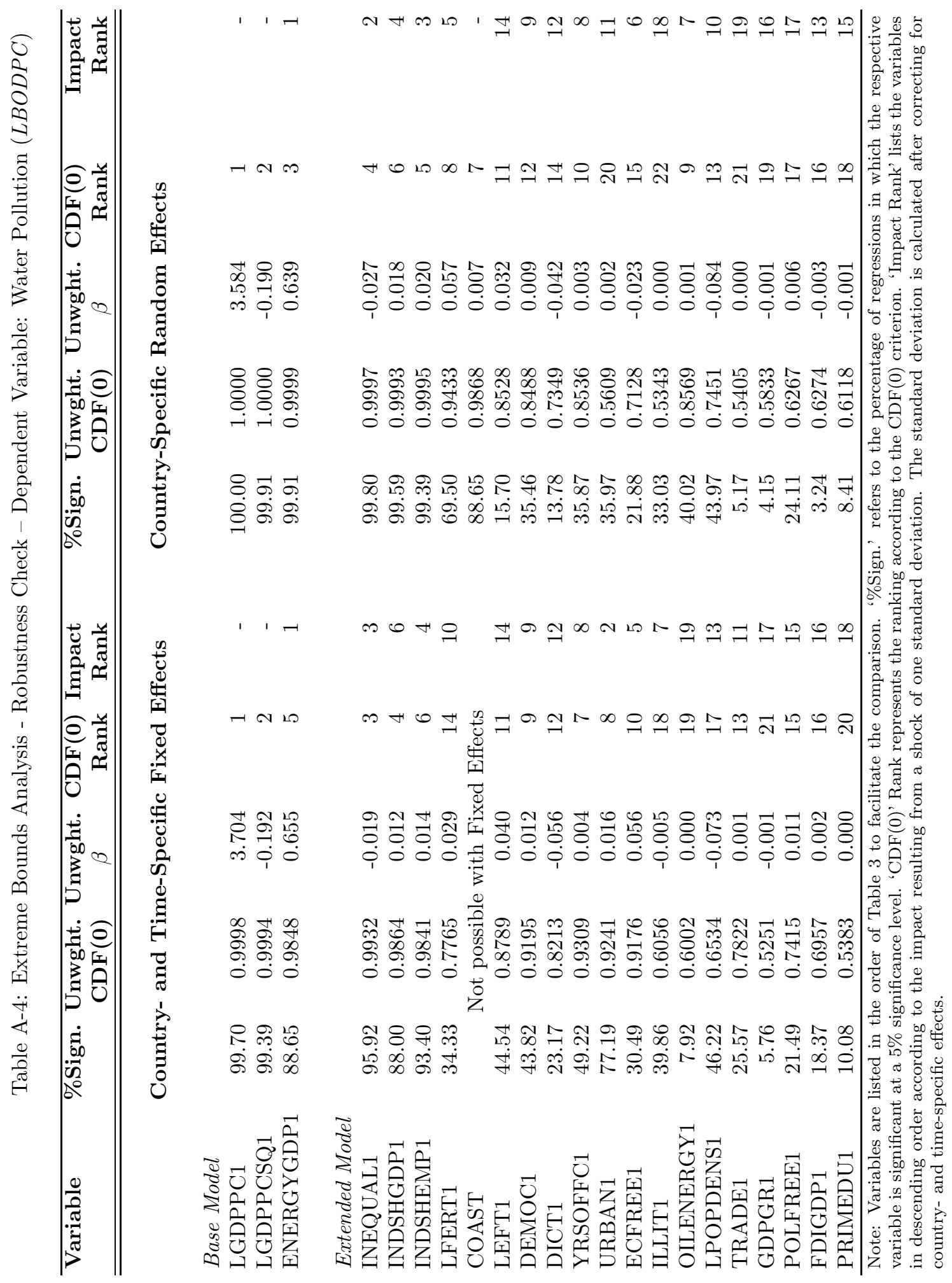




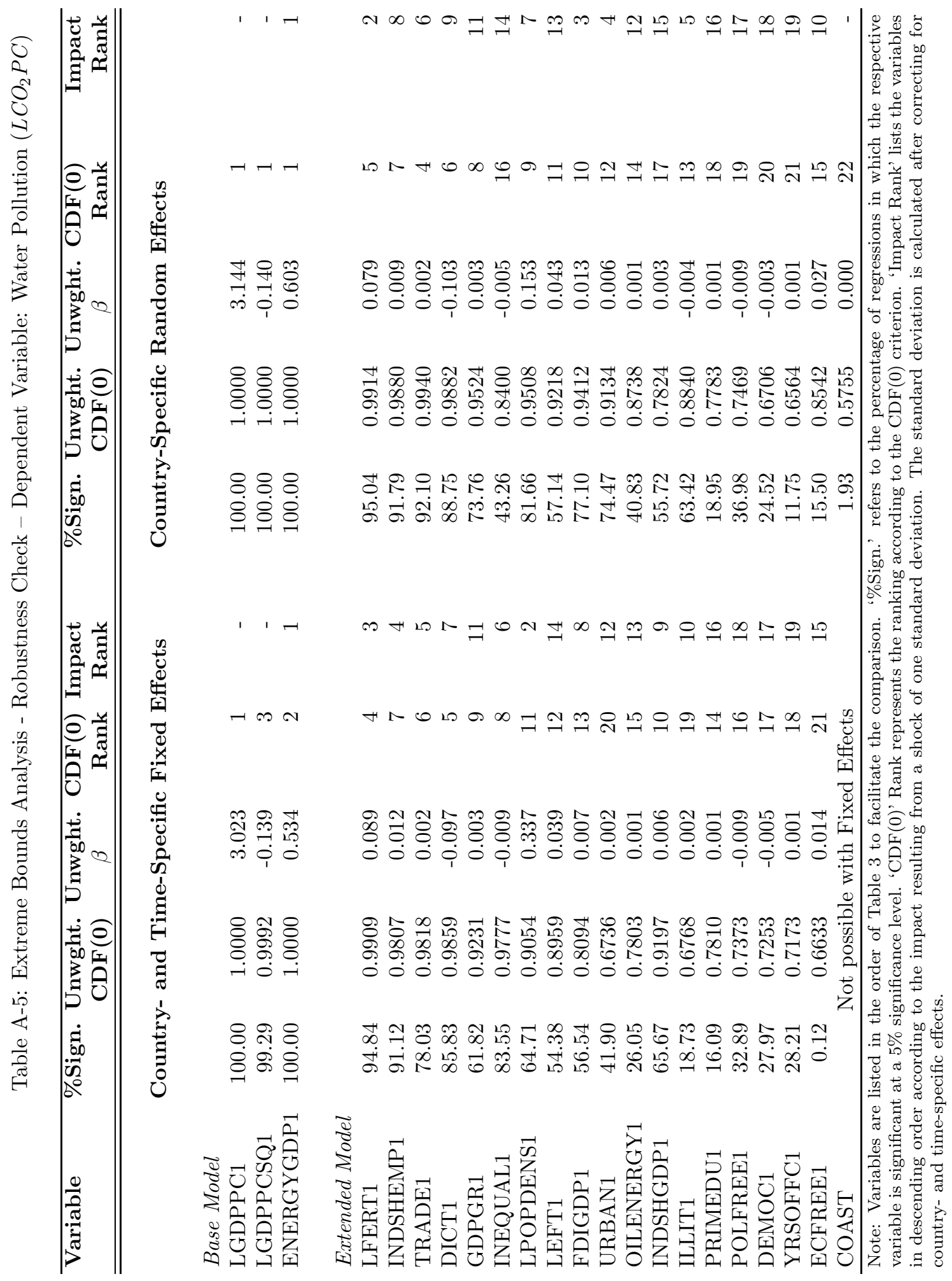


Table A-6: Extreme Bounds Analysis with lagged explanatory variables Dependent variable: Sulfur dioxide $\left(\mathrm{LSO}_{2} \mathrm{PC}\right)$

\begin{tabular}{|c|c|c|c|c|c|c|c|}
\hline Variable & $\begin{array}{l}\text { Lower } \\
\text { Bound }\end{array}$ & $\begin{array}{l}\text { Upper } \\
\text { Bound }\end{array}$ & \%Sign. & $\begin{array}{r}\text { Unwght. } \\
\text { CDF(0) }\end{array}$ & $\begin{array}{c}\text { Unwght. } \\
\beta \\
\end{array}$ & $\begin{array}{r}\text { Std. } \\
\text { Error }\end{array}$ & $\begin{array}{r}\text { Impact } \\
\text { Rank }\end{array}$ \\
\hline \multicolumn{8}{|l|}{$\overline{\overline{\text { Base Model }}}$} \\
\hline LGDPPC1 & -2.713 & 14.251 & 97.67 & 0.9951 & 4.670 & 0.496 & - \\
\hline LGDPPCSQ1 & -0.759 & 0.268 & 93.21 & 0.9585 & -0.227 & 0.030 & - \\
\hline ENERGYGDP1 & -0.261 & 5.329 & 96.25 & 0.9962 & 0.769 & 0.117 & 2 \\
\hline \multicolumn{8}{|l|}{ Extended Model } \\
\hline ILLIT1 & -0.111 & 0.048 & 71.91 & 0.9542 & -0.017 & 0.007 & 3 \\
\hline DICT1 & -0.668 & 0.381 & 46.58 & 0.9327 & -0.109 & 0.061 & 6 \\
\hline LPOPDENS1 & -2.612 & 3.827 & 83.79 & 0.9291 & 1.120 & 0.252 & 1 \\
\hline URBAN1 & -0.055 & 0.079 & 71.91 & 0.9237 & 0.016 & 0.005 & 4 \\
\hline LFERT1 & -0.405 & 0.333 & 66.15 & 0.9038 & 0.081 & 0.035 & 5 \\
\hline LEFT1 & -0.688 & 0.350 & 64.83 & 0.8290 & -0.087 & 0.047 & 7 \\
\hline GDPGR1 & -0.055 & 0.031 & 46.10 & 0.8099 & -0.004 & 0.003 & 8 \\
\hline INEQUAL1 & -0.068 & 0.109 & 36.01 & 0.7542 & -0.007 & 0.008 & 9 \\
\hline FDIGDP1 & -0.112 & 0.116 & 21.49 & 0.7376 & 0.006 & 0.009 & 10 \\
\hline POLFREE1 & -0.202 & 0.114 & 12.36 & 0.6869 & -0.015 & 0.018 & 14 \\
\hline OILENERGY1 & -0.028 & 0.017 & 42.74 & 0.6625 & -0.001 & 0.001 & 11 \\
\hline PRIMEDU1 & -0.030 & 0.022 & 17.41 & 0.6389 & 0.001 & 0.003 & 15 \\
\hline INDSHEMP1 & -0.127 & 0.075 & 26.53 & 0.6155 & 0.002 & 0.007 & 16 \\
\hline INDSHGDP1 & -0.107 & 0.029 & 24.73 & 0.5927 & 0.000 & 0.006 & 18 \\
\hline ECFREE1 & -0.464 & 0.270 & 0.00 & 0.5876 & -0.019 & 0.060 & 12 \\
\hline YRSOFFC1 & -0.030 & 0.020 & 6.36 & 0.5791 & -0.001 & 0.003 & 17 \\
\hline DEMOC1 & -0.055 & 0.085 & 9.84 & 0.5079 & 0.001 & 0.008 & 19 \\
\hline TRADE1 & -0.010 & 0.020 & 18.13 & 0.5050 & 0.001 & 0.001 & 13 \\
\hline
\end{tabular}

Note: Results based on 987 (base model) and 833 (extended model) regressions respectively using country- and time-specific fixed effects. '\%Sign.' refers to the percentage of regressions in which the respective variable is significant at a $5 \%$ significance level. 'Impact Rank' lists the variables in descending order according to the impact resulting from a shock of one standard deviation. The standard deviation is calculated after correcting for country- and time-specific effects. 


\section{CESifo Working Paper Series}

(for full list see www.cesifo-group.de)

1637 Alfons J. Weichenrieder and Oliver Busch, Artificial Time Inconsistency as a Remedy for the Race to the Bottom, December 2005

1638 Aleksander Berentsen and Christopher Waller, Optimal Stabilization Policy with Flexible Prices, December 2005

1639 Panu Poutvaara and Mikael Priks, Violent Groups and Police Tactics: Should Tear Gas Make Crime Preventers Cry?, December 2005

1640 Yin-Wong Cheung and Kon S. Lai, A Reappraisal of the Border Effect on Relative Price Volatility, January 2006

1641 Stefan Bach, Giacomo Corneo and Viktor Steiner, Top Incomes and Top Taxes in Germany, January 2006

1642 Johann K. Brunner and Susanne Pech, Optimum Taxation of Life Annuities, January 2006

1643 Naércio Aquino Menezes Filho, Marc-Andreas Muendler and Garey Ramey, The Structure of Worker Compensation in Brazil, with a Comparison to France and the United States, January 2006

1644 Konstantinos Angelopoulos, Apostolis Philippopoulos and Vanghelis Vassilatos, RentSeeking Competition from State Coffers: A Calibrated DSGE Model of the Euro Area, January 2006

1645 Burkhard Heer and Bernd Suessmuth, The Savings-Inflation Puzzle, January 2006

1646 J. Stephen Ferris, Soo-Bin Park and Stanley L. Winer, Political Competition and Convergence to Fundamentals: With Application to the Political Business Cycle and the Size of Government, January 2006

$1647 \mathrm{Yu}-\mathrm{Fu}$ Chen, Michael Funke and Kadri Männasoo, Extracting Leading Indicators of Bank Fragility from Market Prices - Estonia Focus, January 2006

1648 Panu Poutvaara, On Human Capital Formation with Exit Options: Comment and New Results, January 2006

1649 Anders Forslund, Nils Gottfries and Andreas Westermark, Real and Nominal Wage Adjustment in Open Economies, January 2006

1650 M. Hashem Pesaran, Davide Pettenuzzo and Allan G. Timmermann, Learning, Structural Instability and Present Value Calculations, January 2006 
1651 Markku Lanne and Helmut Luetkepohl, Structural Vector Autoregressions with Nonnormal Residuals, January 2006

1652 Helge Berger, Jakob de Haan and Jan-Egbert Sturm, Does Money Matter in the ECB Strategy? New Evidence Based on ECB Communication, January 2006

1653 Axel Dreher and Friedrich Schneider, Corruption and the Shadow Economy: An Empirical Analysis, January 2006

1654 Stefan Brandauer and Florian Englmaier, A Model of Strategic Delegation in Contests between Groups, January 2006

1655 Jan Zápal and Ondřej Schneider, What are their Words Worth? Political Plans and Economic Pains of Fiscal Consolidations in New EU Member States, January 2006

1656 Thiess Buettner, Sebastian Hauptmeier and Robert Schwager, Efficient Revenue Sharing and Upper Level Governments: Theory and Application to Germany, January 2006

1657 Daniel Haile, Abdolkarim Sadrieh and Harrie A. A. Verbon, Cross-Racial Envy and Underinvestment in South Africa, February 2006

1658 Frode Meland and Odd Rune Straume, Outsourcing in Contests, February 2006

1659 M. Hashem Pesaran and Ron Smith, Macroeconometric Modelling with a Global Perspective, February 2006

1660 Alexander F. Wagner and Friedrich Schneider, Satisfaction with Democracy and the Environment in Western Europe - a Panel Analysis, February 2006

1661 Ben J. Heijdra and Jenny E. Ligthart, Fiscal Policy, Monopolistic Competition, and Finite Lives, February 2006

1662 Ludger Woessmann, Public-Private Partnership and Schooling Outcomes across Countries, February 2006

1663 Topi Miettinen and Panu Poutvaara, Political Parties and Network Formation, February 2006

1664 Alessandro Cigno and Annalisa Luporini, Optimal Policy Towards Families with Different Amounts of Social Capital, in the Presence of Asymmetric Information and Stochastic Fertility, February 2006

1665 Samuel Muehlemann and Stefan C. Wolter, Regional Effects on Employer Provided Training: Evidence from Apprenticeship Training in Switzerland, February 2006

1666 Laszlo Goerke, Bureaucratic Corruption and Profit Tax Evasion, February 2006

1667 Ivo J. M. Arnold and Jan J. G. Lemmen, Inflation Expectations and Inflation Uncertainty in the Eurozone: Evidence from Survey Data, February 2006 
1668 Hans Gersbach and Hans Haller, Voice and Bargaining Power, February 2006

1669 Françoise Forges and Frédéric Koessler, Long Persuasion Games, February 2006

1670 Florian Englmaier and Markus Reisinger, Information, Coordination, and the Industrialization of Countries, February 2006

1671 Hendrik Hakenes and Andreas Irmen, Something out of Nothing? Neoclassical Growth and the 'Trivial' Steady State, February 2006

1672 Torsten Persson and Guido Tabellini, Democracy and Development: The Devil in the Details, February 2006

1673 Michael Rauber and Heinrich W. Ursprung, Evaluation of Researchers: A Life Cycle Analysis of German Academic Economists, February 2006

1674 Ernesto Reuben and Frans van Winden, Reciprocity and Emotions when Reciprocators Know each other, February 2006

1675 Assar Lindbeck and Mats Persson, A Model of Income Insurance and Social Norms, February 2006

1676 Horst Raff, Michael Ryan and Frank Staehler, Asset Ownership and Foreign-Market Entry, February 2006

1677 Miguel Portela, Rob Alessie and Coen Teulings, Measurement Error in Education and Growth Regressions, February 2006

1678 Andreas Haufler, Alexander Klemm and Guttorm Schjelderup, Globalisation and the Mix of Wage and Profit Taxes, February 2006

1679 Kurt R. Brekke and Lars Sørgard, Public versus Private Health Care in a National Health Service, March 2006

1680 Dominik Grafenhofer, Christian Jaag, Christian Keuschnigg and Mirela Keuschnigg, Probabilistic Aging, March 2006

1681 Wladimir Raymond, Pierre Mohnen, Franz Palm and Sybrand Schim van der Loeff, Persistence of Innovation in Dutch Manufacturing: Is it Spurious?, March 2006

1682 Andrea Colciago, V. Anton Muscatelli, Tiziano Ropele and Patrizio Tirelli, The Role of Fiscal Policy in a Monetary Union: Are National Automatic Stabilizers Effective?, March 2006

1683 Mario Jametti and Thomas von Ungern-Sternberg, Risk Selection in Natural Disaster Insurance - the Case of France, March 2006

1684 Ken Sennewald and Klaus Waelde, "Itô's Lemma" and the Bellman Equation for Poisson Processes: An Applied View, March 2006 
1685 Ernesto Reuben and Frans van Winden, Negative Reciprocity and the Interaction of Emotions and Fairness Norms, March 2006

1686 Françoise Forges, The Ex Ante Incentive Compatible Core in Exchange Economies with and without Indivisibilities, March 2006

1687 Assar Lindbeck, Mårten Palme and Mats Persson, Job Security and Work Absence: Evidence from a Natural Experiment, March 2006

1688 Sebastian Buhai and Coen Teulings, Tenure Profiles and Efficient Separation in a Stochastic Productivity Model, March 2006

1689 Gebhard Kirchgaessner and Silika Prohl, Sustainability of Swiss Fiscal Policy, March 2006

1690 A. Lans Bovenberg and Peter Birch Sørensen, Optimal Taxation and Social Insurance in a Lifetime Perspective, March 2006

1691 Moritz Schularick and Thomas M. Steger, Does Financial Integration Spur Economic Growth? New Evidence from the First Era of Financial Globalization, March 2006

1692 Burkhard Heer and Alfred Maussner, Business Cycle Dynamics of a New Keynesian Overlapping Generations Model with Progressive Income Taxation, March 2006

1693 Jarko Fidrmuc and Iikka Korhonen, Meta-Analysis of the Business Cycle Correlation between the Euro Area and the CEECs, March 2006

1694 Steffen Henzel and Timo Wollmershaeuser, The New Keynesian Phillips Curve and the Role of Expectations: Evidence from the Ifo World Economic Survey, March 2006

1695 Yin-Wong Cheung, An Empirical Model of Daily Highs and Lows, March 2006

1696 Scott Alan Carson, African-American and White Living Standards in the $19^{\text {th }}$ Century American South: A Biological Comparison, March 2006

1697 Helge Berger, Optimal Central Bank Design: Benchmarks for the ECB, March 2006

1698 Vjollca Sadiraj, Jan Tuinstra and Frans van Winden, On the Size of the Winning Set in the Presence of Interest Groups, April 2006

1699 Martin Gassebner, Michael Lamla and Jan-Egbert Sturm, Economic, Demographic and Political Determinants of Pollution Reassessed: A Sensitivity Analysis, April 2006 